CAROLINE MARQUES LEAL JORGE SANTOS

Poluição das águas por contaminantes emergentes: contribuições para uma tutela autônoma fundada na precaução

Dissertação de Mestrado

Orientadora: Professora Associada Doutora Patrícia Faga Iglecias Lemos

UNIVERSIDADE DE SÃO PAULO

FACULDADE DE DIREITO

São Paulo-SP

2018 



\section{Poluição das águas por contaminantes emergentes: contribuições para uma tutela autônoma fundada na precaução}

Dissertação apresentada à Banca Examinadora do Programa de Pós-Graduação em Direito, da Faculdade de Direito da Universidade de São Paulo, como exigência parcial para obtenção do título de Mestre em Direito, na área de concentração Direito Civil, sob a orientação do Professora Associada Doutora Patrícia Faga Iglecias Lemos.

UNIVERSIDADE DE SÃO PAULO

FACULDADE DE DIREITO

São Paulo-SP 
Catalogação da Publicação

Serviço de Biblioteca e Documentação

Faculdade de Direito da Universidade de São Paulo

Santos, Caroline Marques Leal Jorge

Poluição das águas por contaminantes emergentes: contribuições para uma tutela autônoma fundada na precaução / Caroline Marques Leal Jorge Santos ; orientadora Patrícia Faga Iglecias Lemos -- São Paulo, 2018.

$165 \mathrm{p}$.

Dissertação (Mestrado - Programa de Pós-Graduação em Direito Civil) Faculdade de Direito, Universidade de São Paulo, 2018.

1. Responsabilidade ambiental. 2. Contaminação de águas. 3. Contaminantes emergentes. 4. Sociedade de risco. 5. Precaução. I. Lemos, Patrícia Faga Iglecias, orient. II. Título. 
BANCA EXAMINADORA 

Ao meu amor e ao caudex dessa nossa incrível história.

Também aos meus amados pais, razão de ser quem eu sou e de poder chegar onde estou. 



\section{AGRADECIMENTOS}

“O reino de Deus está dentro de ti e a tua volta [...]. Rache uma lasca de madeira e Eu estarei lá. Levante uma pedra e Me encontrarás”. A Deus rendo aqui não um agradecimento - pois creio não haver, algures, palavra capaz de traduzir essa gratidão -, mas um registro singelo de que Ele, em sua infinita misericórdia, é a força de tudo.

Aos meus primeiros professores, Sonia e Edson. Ao meu pai, que me legou o amor pelo direito, forjou o exemplo de profissional dedicado e ser humano íntegro que me esforço a seguir. Obrigada por me ensinar, desde cedo, que não há atalhos ou caminhos fáceis na vida, e que é preciso coragem, paciência e (às vezes uma bela dose de) teimosia para percorrê-la. À minha mãe querida: como agradecer todo seu amor e dedicação? Seus sacrifícios estarão para sempre gravados em minha mente, tanto quanto o gosto ruim das sopas - cuja composição prefiro não saber - que você fazia com tanto carinho para me deixar forte e inteligente! Acho que você nunca compreenderá a força que tem e a influência que sempre exerceu sobre mim. Tenho certeza de que a vovó, onde quer que esteja, zela por nós, e vê orgulhosa a pessoa maravilhosa que você é.

À Professora Patrícia, minha orientadora. Meus agradecimentos por me acolher na pós-graduação, com a generosidade que lhe é característica. O que dizer a quem, mais do que orientar, verdadeiramente inspira? Àquela cuja capacidade de liderança e energia não permite que nos abatamos mesmo diante das maiores dificuldades? Sem seu incondicional apoio e confiança, sei que nada disso teria sido possível.

"De tudo, ao meu amor serei atento antes". Ao meu marido, que eu possa até o fim de meus dias lhe dizer do amor infinito que tenho. Obrigada por seu amor, seu encorajamento - e até suas cobranças -, mas especialmente pela infinita paciência a cada acender de luzes e tilintar das teclas do laptop madrugadas afora ao longo do mestrado.

Também não poderia deixar de agradecer à minha querida sogra, Maria Clara, exemplo de mulher, por todas as vibrações espirituais.

Por fim, resta-me a dívida impagável aos tantos queridos amigos, pelo carinho e por toda forma de ajuda ao longo desse percurso. Sei que não estive sozinha. Cada gesto, ainda que pequeno, cada palavra de incentivo serviram-me como alento nos momentos de insegurança. Longe ou perto, encontro vocês em meu coração, onde guardo a certeza de ser querida. 

"Let us reconcile ourselves to the mysterious rhythm of our destinies [...]. Let us treasure our joys but not bewail our sorrows.

The glory of light cannot exist without its shadows. Life is a whole, and good and ill must be accepted together.

The journey has been enjoyable and well worth making - once."

(Churchill) 



\section{RESUMO}

SANTOS, Caroline Marques Leal Jorge. Poluição das águas por contaminantes emergentes: contribuições para uma tutela autônoma fundada na precaução. 2018. 165 p. Dissertação (Mestrado em Direito) - Faculdade de Direito da Universidade de São Paulo, São Paulo, 2018.

Inicialmente, o presente trabalho retrocede às origens do direito e da sua fragmentação em direito civil e penal, com o escopo de analisar o surgimento da disciplina ambiental, sob uma perspectiva marcadamente antropocêntrica. Em seguida, é objeto de estudo a contaminação das águas por poluentes emergentes, seus possíveis danos e atuais repercussões jurídicas. A partir daí, analisa o desenvolvimento da responsabilidade ambiental em ambas as disciplinas, assim como o florescimento de uma função preventiva, sob a égide da sociedade de risco. Por fim, traça a interseção da temática civil com a seara criminal, a aferir se a proteção do meio ambiente pode prescindir de uma tutela conjunta ou coordenada, diante do aprofundamento dos problemas ambientes, para então esboçar, de um lado, os principais desafios, e, de outro, os fundamentos para uma tutela autônoma da responsabilidade pela poluição das águas por contaminantes emergentes, sob os auspícios do princípio da precaução.

Palavras-chave: Responsabilidade ambiental. Contaminação de águas. Contaminantes emergentes. Sociedade de risco. Precaução. 


\begin{abstract}
SANTOS, Caroline Marques Leal Jorge. Water pollution by emerging contaminants: contributions for an autonomous tutelage based on precaution. 2018. 165 p. Dissertation (Master in Law) - Faculdade de Direito da Universidade de São Paulo, São Paulo, 2018.

Initially, the present work will go back to the origins of Law and its fragmentation into Civil and Criminal Law, aiming to analyze the emergence of the environmental discipline from a markedly anthropocentric perspective. Next, water contamination by emerging pollutants will be object of study, its possible damages and current legal repercussions. Thereafter, the evolution of the responsibility theory of both disciplines will be presented, as well as the flourishing of a precautionary function under the aegis of the so-called risk society. Finally, tracing the intersection of the civil subject with the criminal realm, it will be assessed if environmental protection can be achieved without a joint or coordinated tutelage in face of the deepening of the environment problems. The main challenges on one hand and the theoretical foundations under the auspices of the precautionary principle on the other will then be sketched, for an autonomous tutelage of the responsibility for the contamination of water by emerging contaminants.
\end{abstract}

Keywords: Environmental responsibility. Water contamination. Emerging contaminants. Risk society. Precaution. 


\section{SUMÁRIO}

INTRODUÇÃO

CAPÍTULO 1 - ORIGENS DO DIREITO E DA PROTEÇÃO AMBIENTAL 25

1.1 A formação do direito e da ciência do direito .................................................................25

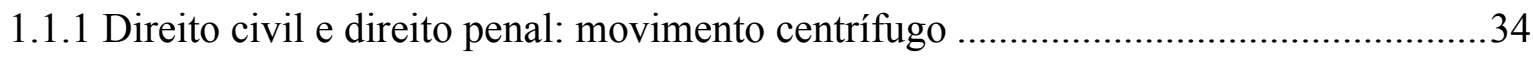

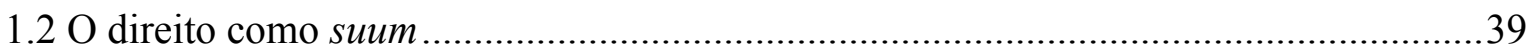

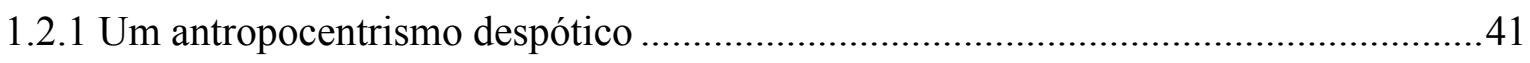

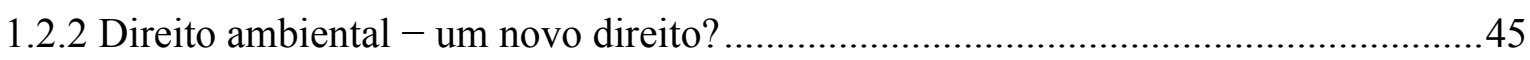

CAPÍTULO 2 - PROTEÇÃO DAS ÁGUAS E CONTAMINANTES EMERGENTES ...49

2.1 Panorama atual da proteção das águas ........................................................................49

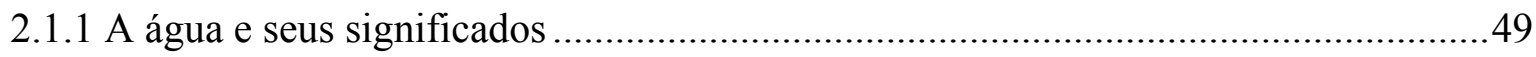

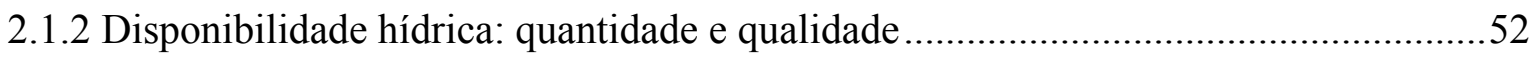

2.1.3 Delimitação dos conceitos de poluição e de contaminação e as respectivas

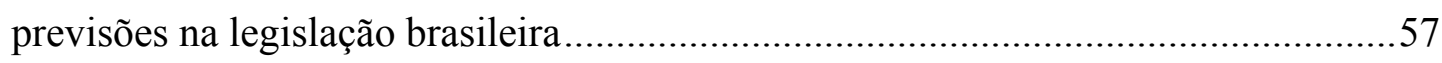

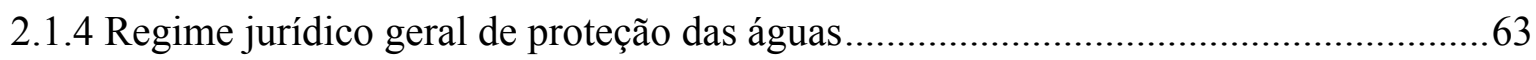

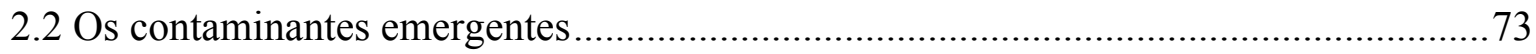

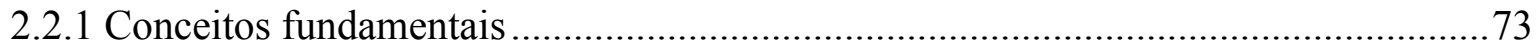

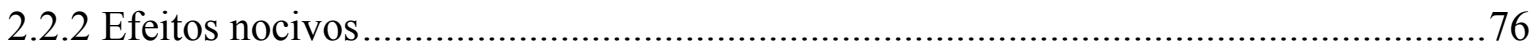

CAPÍTULO 3 - RESPONSABILIDADE AMBIENTAL NA SOCIEDADE DE RISCO..87

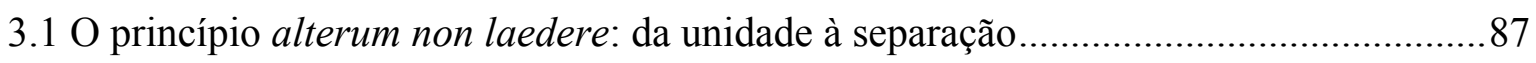

3.2 Responsabilidade civil tradicional e a insuficiência da reparação ...............................93

3.2.1 A evolução da responsabilidade civil - da culpa ao risco ........................................95

3.2.2 Erosão dos demais pressupostos: nexo de causalidade e dano ...................................99

3.2.3 Função preventiva da responsabilidade civil e sociedade de risco ........................... 108

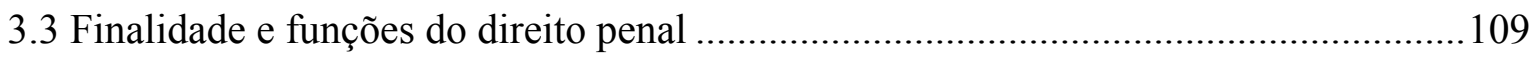

3.3.1 Noção de bem jurídico e bem jurídico ambiental ...................................................... 116

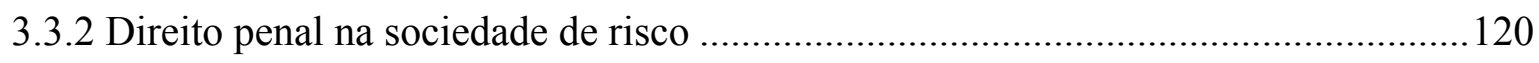

3.3.3 Âmbito punitivo da proteção das águas e os contaminantes emergentes.

Limites e subsidiariedade da proteção penal ...........................................................122 
3.4 Precaução como elo das responsabilidades pela poluição das águas por

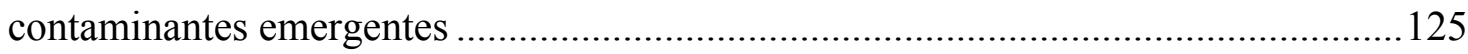

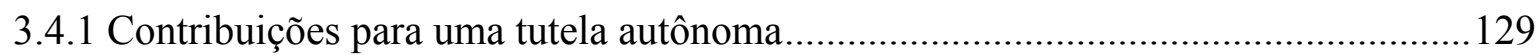

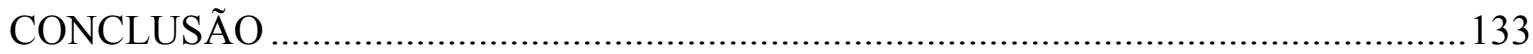

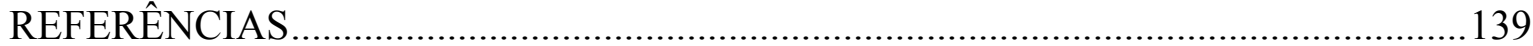




\section{INTRODUÇÃO}

Há um consenso crescente acerca da afirmação do direito ambiental como um novo ramo na história do direito.

Não obstante, diferentemente dos ancestrais institutos jurídicos, intrinsecamente relacionados à formação do próprio homem enquanto ser social, podemos dizer que a disciplina do meio ambiente origina-se a partir de sua "deformação".

Com efeito, muito embora o surgimento da espécie humana seja apenas um capítulo recente numa história de 4,56 bilhões de $\operatorname{anos}^{1}$, em pouco mais de três séculos, contados a partir do aparecimento do capitalismo como fenômeno econômico, a atividade antrópica subjugou os recursos planetários de tal forma que pode ter-lhe infligido um dramático, e talvez traumático, epílogo.

Assim, o direito ambiental emerge em razão da necessidade de se estabelecer uma regulação normativa para a nova relação do homem com a natureza, que a partir da Revolução Industrial, deixou de significar um relativo equilíbrio, para pautar-se na utilização de recursos finitos como se infinitos fossem.

Em outros termos, o aumento contínuo dos padrões de produção e consumo a partir do século XVIII, aliado ao exponencial crescimento da própria população nos séculos seguintes, levaram a um expressivo decréscimo dos recursos naturais e, na mesma proporção, ao acréscimo considerável da degradação ambiental.

Mas foi apenas em 1972, no seio da Conferência de Estocolmo, que a temática ambiental foi sistematicamente levada ao cenário internacional, através das discussões de estudos alicerçados numa linha malthusiana, os quais prognosticavam um possível colapso da economia mundial, a partir dos níveis cada vez maiores de apropriação da natureza. A escassez e a degradação, portanto, estão na origem do conceito de desenvolvimento

\footnotetext{
${ }^{1}$ MARTINS, Veridiana T. de S.; BABINSKI, Marly. Geocronologia: o tempo registrado nas rochas. Instituto de Geociências da USP. Disponível em: <http:/www.igc.usp.br/index.php?id=304>. Acesso em: 25 jan. 2017.
} 
sustentável concebido no Relatório Brundtland e ainda na necessidade, progressivamente internalizada pelos mais diversos países, de positivação da natureza.

Todavia, a despeito dos esforços teóricos, na prática o que se viu foi a continuidade de um modelo autofágico, cujo espectro sombrio mais visível toma a forma cada vez mais recorrente de desastres ambientais.

Por conseguinte, a ignorância acerca dos impactos, decorrentes seja da manipulação da natureza, seja do exaurimento de seus recursos, isto é, o risco dos danos ambientais, marca a atual sociedade com a forja do medo.

Nas palavras de Ulrich Beck: "Na modernidade desenvolvida [...] emerge um novo tipo de destino 'adstrito' em função do perigo, do qual nenhum esforço permite escapar. [...] sob o signo do medo; ele não é um 'resíduo tradicional', mas um produto da modernidade, particularmente em seu estágio mais avançado."²

Ao estremecer os fundamentos da sociedade moderna, o perigo traça um novo curso à humanidade e cria as condições para a construção da intitulada "sociedade de risco", regida pela máxima segundo a qual "não há nada certo além da incerteza". 3

Para Hans Jonas, estar-se-ia diante não mais da ponderação de perdas e ganhos, mas “do perigo, não mais passível de qualquer ponderação, da perda infinita diante da oportunidade de ganhos finitos". ${ }^{4}$

Isso posto, mister reconhecer que talvez a maior ameaça à nossa civilização resida na questão da água, recurso sine qua non a toda forma de vida no planeta, e que confere suporte às mais diversas atividades humanas, tendo desempenhado ao longo da história papel central no surgimento de algumas das grandes civilizações, tais como no Egito, Mesopotâmia, Grécia, Índia e China.

\footnotetext{
${ }^{2}$ BECK, Ulrich. Sociedade de risco: rumo a uma outra modernidade. 2. ed., reimpr. Tradução de Sebastião Nascimento. São Paulo: Editora 34, 2013.p. 8.

${ }^{3}$ BECK, Ulrich. Incertezas fabricadas (Entrevista). Revista IHU ONLINE, Sociedade do risco: o medo na contemporaneidade, São Leopoldo, RS, n. 181, p. 5-12, 22 maio 2006. Disponível em: $<$ http://www.ihuonline.unisinos.br/media/pdf/IHUOnlineEdicao181.pdf.>. Acesso em: 25 jan. 2017.

${ }^{4}$ JONAS, Hans. O princípio responsabilidade: ensaio de uma ética para a civilização tecnológica. Tradução de Marijane Lisboa e Luiz Barros Montez. Rio de Janeiro: Contraponto; Editora PUC-Rio, 2006. p. 80.
} 
Paradoxalmente, embora a água seja o recurso mais abundante do planeta, recobrindo em torno de $70 \%{ }^{5}$ de sua superfície, apenas uma ínfima parcela corresponde à água doce aproveitável.

De acordo com dados do Programa das Nações Unidas para o Meio Ambiente $(\text { PNUMA })^{6}$, do volume total existente em nosso planeta, apenas 2,5\% correspondem a água doce, dos quais mais de 99\% encontram-se indisponíveis, na forma de gelo e neve permanente, ou em aquíferos extremamente profundos.

E esse $1 \%$ restante de água doce, ou 0,01\% do total de água na Terra, utilizado por uma população aproximada de 7,2 bilhões de habitantes ${ }^{7}$, atingiu um estágio tal de degradação que hoje mais pessoas morrem em decorrência de doenças relacionadas à água contaminada do que de todas as formas de violência, inclusive a guerra. ${ }^{8}$

Feitas essas iniciais considerações e face às múltiplas formas de interferência antrópica, o presente trabalho pretende estabelecer um recorte temático sobre os contaminantes emergentes.

A delimitação é realizada considerando que malgrado se discuta frequentemente a poluição das águas, parte considerável dos contaminantes remanesce desconhecida da população e, por vezes, da própria ciência.

${ }^{5}$ GROTZINGER, John; JORDAN, Tom. Para entender a Terra. Tradução de Iuri Duquia Abreu. 6. ed. Porto Alegre: Bookman. 2013. p. 475.

${ }^{6}$ ESTADO do meio ambiente e retrospectivas políticas: 1972-2002: água doce. In: PROGRAMA DAS NAÇÕES UNIDAS PARA MEIO AMBIENTE (PNUMA). Perspectivas do meio ambiente mundial 2002 GEO-3: passado, presente e futuro. Brasília: IBAMA/PNUMA, 2004. Cap. 2, p. 162-197. Disponível em: $<\mathrm{http} / / /$ www.wwiuma.org.br/geo mundial_arquivos/cap2 \%20aguadoce.pdf $>$. Acesso em: 20 maio 2017.

${ }^{7}$ ONU: população mundial é de 7,2 bilhões de pessoas. Estadão, Internacional, São Paulo, 13 de junho de 2013. Disponível em: <http://internacional.estadao.com.br/noticias/geral,onu-populacao-mundial-e-de-7-2bilhoes-de-pessoas, 1042156 $\geq$. Acesso em: 21 maio 2017.

${ }^{8}$ CORCORAN, Emily et al. (Eds.). Sick water?: the central role of waste-water management in sustainable development: a rapid response assessment. Arendal, Norway: United Nations Environment Programme UNEP/GRID-Arendal; Nairobi, Kenya: UN-HABITAT, GRID-Arendal, 2010. Disponível em: $<\mathrm{https}$ :/gridarendal-

website.s3.amazonaws.com/production/documents/:s_document/208/original/SickWater_screen.pdf?14867

21310>. Acesso em: 09 out. 2017. 
Com efeito, dos cerca de 85.000 agentes químicos produzidos nos países mais industrializados, menos de $10 \%$ foram submetidos a testes de efeitos toxicológicos em organismos em desenvolvimento, antes de serem comercializados. ${ }^{9}$

A cada ano, mais de 1.500 substâncias novas são lançadas no mercado ${ }^{10}$, resultado do contínuo crescimento dos padrões de produção de uma sociedade orientada para o consumo de massa.

Desse universo, parcela expressiva constitui os chamados contaminantes emergentes, termo que, conquanto careça de definição jurídica, é largamente utilizado pela ciência química para referir-se a novas substâncias que, destinadas a múltiplos usos (pessoal, agrícola ou industrial), sejam potencialmente causadoras de efeitos adversos à saúde animal e humana. O termo também é aplicado para substâncias antigas, mas que eram desconhecidas, em razão da inexistência de tecnologia para sua detecção. ${ }^{11}$

Portanto, contaminantes emergentes são poluentes que literalmente emergiram na sociedade de risco.

Tais substâncias podem ser encontradas nos mais diversos produtos, e.g. os de higiene pessoal, pesticidas e fármacos, especialmente aqueles com atividade estrogênica, havendo diversos registros na literatura científica de estudos a associar os contaminantes emergentes com uma série de interferências, incluindo variadas formas de cânceres, tanto nos animais quanto em seres humanos. ${ }^{12}$

\footnotetext{
${ }^{9}$ MELLO-DA-SILVA, Carlos Augusto; FRUCHTENGARTEN, Ligia. Riscos químicos ambientais à saúde da criança. Jornal de Pediatria, (Rio J.), Porto Alegre, v. 81, n. 5, supl. p. s205-s211, nov. 2005. Disponível em: $\quad<$ http://www.scielo.br/scielo.php?script=sci_arttext\&pid=S0021$75572005000700011 \& \operatorname{lng}=\mathrm{en} \& \mathrm{nrm}=\mathrm{iso} \& \mathrm{tlng}=\mathrm{pt}>$. Acesso em: 12 jul. 2017.

${ }^{10}$ ALVES FILHO, Manuel. Potável, porém contaminada. Jornal da Unicamp, Campinas, de 21 a 27 de maio de 2012, ANO 2012, n. 527, p. 3. Disponível em: $<$ http://www.unicamp.br/unicamp/sites/default/files/jornal/paginas/pagina3A_1.pdf $>$. Acesso em: 05 out. 2017.

${ }^{11}$ PALANIAPPAN, Meena et al. Clearing the waters: a focus on water quality solutions. Nairobi, Kenya: United Nations Environment Programme (UNEP), 2010. Disponível em: $<$ http://pacinst.org/publication/clearing-the-waters-focus-on-water-quality-solutions/>. Acesso em: 09 out. 2017.

12 A afirmação apoia-se em vasta literatura científica. Nesse sentido: "Estudos feitos em laboratório com animais expostos a diversas substâncias consideradas IEs têm demonstrado malformações congênitas, diminuição da fertilidade, alterações na espermatogênese, entre outras disfunções (ZOU e FINGERMAN, 1997; TAKEMURA e KIM, 2001; HSU, GUO e LI, 2004; MCALLISTTER e KIME, 2003; DENSLOW et al., 2004; LEE et al., 2004; LIND et al., 2004; NEWBOLD et. al 2004; SCHOLZ et. al, 2004; STOKESA et. al, 2004; VAN DEN BELT et. al, 2004; MA et. al, 2005; MARANGHI et al., 2007);" (SILVA, Ana
} 
Evidente que, nesse cenário, a elucidação dos efeitos deletérios ocorre num ritmo infinitamente menor do que a produção e o lançamento de tais produtos e, nem se diga, a evolução legislativa.

Nesse sentido, Ulrich Beck é categórico ao afirmar que, na "globalidade da contaminação", os "sistemas jurídicos não dão conta das situações de fato". ${ }^{13}$

Isso posto, considerando que os contaminantes emergentes são exemplos emblemáticos dos danos ambientais velados advindos da sociedade pós-industrial, que estão a demandar uma maior atenção sob o prisma jurídico, o subsequente recorte temático recai na responsabilidade. O presente trabalho pretende levar a cabo uma abordagem bifronte, civil e ambiental, a fim de verificar a viabilidade de uma tutela autônoma fundada na precaução.

De outro ângulo, a partir da premissa da incerteza inerente à sociedade de risco, objetiva-se traçar o panorama atual da proteção conferida por ambas as disciplinas à poluição das águas por contaminantes emergentes, identificando eventuais incompatibilidades com os paradigmas tradicionais da responsabilidade. A partir da análise da efetividade de cada modelo isoladamente, investigar-se-á a perspectiva de uma responsabilidade ambiental arquetípica, capaz de conter, harmônica e coordenadamente, as repercussões civis e penais aplicadas à poluição por contaminantes emergentes.

A hipótese levantada funda-se numa constatação empírica: novos problemas impõem novos instrumentos jurídicos. A proteção ambiental, lato sensu, demanda uma teoria da responsabilidade considerando a multiplicidade de agentes poluidores, a dispersão dos contaminantes que não comportam limites geográficos, a cumulatividade de

Lúcia. Interferentes endócrinos no meio ambiente: um estudo de caso em amostras de água in natura e efluente de estação de tratamento de esgotos da região metropolitana de São Paulo. Tese (Doutorado) Faculdade de Saúde Pública, Universidade de São Paulo, São Paulo, 2009. p. 39-40 Disponível em: $<$ http://www.teses.usp.br/teses/disponiveis/6/6134/tde-21072009-091520/>. Acesso em: 12 jul. 2017). Já com relação aos efeitos em seres humanos: "Em 1999 o Scientific Committee for Toxicity, Ecotoxicity and the Environment (SCTEE), emitiu um parecer no qual, após análise da literatura e dos pareceres científicos existentes sobre as provas de IE de origem química, conclui que, com relação à saúde humana, 'há associações entre as substâncias químicas causadoras de interferência endócrina estudadas até agora e alterações da saúde humana', como o câncer de testículo, da mama e da próstata, a queda de taxa de produção de espermatozóides, deformidades dos órgãos reprodutivos, disfunção da tireóide e comprometimento da inteligência e do sistema neurológico." (Ibidem, p. 38).

${ }^{13}$ BECK, Ulrich, Sociedade de risco: rumo a uma outra modernidade, cit., p. 10. 
seus efeitos e a falta de certeza científica a comprometer a qualidade de vida das gerações do porvir.

Nas palavras de Hans Jonas, a "natureza como uma responsabilidade humana é seguramente um novum" ${ }^{14}$, para o qual, acrescente-se, a responsabilidade essencialmente calcada na reparação, ou na repressão, não parece mais ser suficiente.

Sem embargo, para o fim proposto, torna-se necessário retroceder à origem da responsabilidade jurídica, da qual despontaram as responsabilidades civil e penal.

Percorrendo os caminhos que levaram cada matéria a desenvolver um sistema com objetivos próprios, será possível inferir em que medida são eles aptos a garantir a higidez ambiental.

Modernamente, fala-se muito acerca da hipertrofia da responsabilidade civil e do simbolismo do direito penal. Nesse sentido, a atividade legislativa e jurisprudencial é farta de exemplos, de parte a parte. À primeira vista, parece que tais excessos estão relacionados fundamentalmente à tarefa que cada uma das disciplinas se impôs, de tutelar integralmente determinadas questões ambientais, ultrapassando, com seus meios, os próprios fins.

Ao cabo de tais considerações, nas hipóteses de poluição das águas por contaminantes emergentes, seria viável a construção de um sistema de responsabilidade que, para além de civil ou penal, fosse, antes e acima de tudo, ambiental?

Como dito, as questões acima apontadas são orientadas pela lógica da precaução, a qual proclama, diante da inexistência do "risco zero", que mais vale evitar um possível dano que repará-lo.

Em que medida, entretanto, a prevenção poderá valer-se da repressão penal?

Assim, para analisar a problemática de uma responsabilidade ambiental, propõe-se a utilização do método fenomenológico-hermenêutico, com técnicas de investigação teórica histórica, conceitual e normativa. ${ }^{15}$

\footnotetext{
${ }^{14}$ JONAS, Hans, O princípio responsabilidade: ensaio de uma ética para a civilização tecnológica, cit., p. 39.

${ }^{15}$ BITTAR, Eduardo Carlos Bianca. Metodologia da pesquisa jurídica. 14. ed. São Paulo: Saraiva, 2016. p. $170-176$.
} 
Nas palavras de Nélson Hungria:

\begin{abstract}
A ciência que estuda, interpreta e sistematiza o direito [...] não pode fazer-se cega à realidade, sob pena de degradar-se numa sucessão de fórmulas vazias, numa platitude obsedante de mapa mural de geometria. Ao invés de librar-se aos pináculos da dogmática, tem de vir para o chão do átrio onde ecoa o rumor das ruas, o vozeio da multidão, o estrépito da vida, o fragor do mundo, o bramido da tragédia humana. ${ }^{16}$
\end{abstract}

Feitas essas considerações, passa-se a indicar o conteúdo dos quatro capítulos que compõem o presente trabalho.

No Capítulo 1 serão analisados, a partir de uma perspectiva funcional e antropocêntrica, a origem e o desenvolvimento do direito, até a formação dos sistemas de proteção do meio ambiente e de defesa das águas, destacando-se o processo histórico de individualização dos direitos civil e penal. ${ }^{17}$

Apresentar-se-á no Capítulo 2 um "estado da arte" em matéria de poluição das águas por contaminantes emergentes, considerando o arcabouço tanto das ciências exatas e biológicas, quanto das ciências jurídicas. Nesse último enfoque, a partir de um método indutivo acerca dos possíveis danos relacionados aos contaminantes emergentes, será explorada a conveniência de uma abordagem preventiva.

Aprofundando a investigação principiada no Capítulo 1, no Capítulo 3 será escrutada a função e estrutura da responsabilidade (civil e penal), sua efetividade e suficiência, notadamente quanto à capacidade de antecipação de riscos por meio da precaução, objetivando traçar os fundamentos para uma tutela autônoma da responsabilidade pela poluição das águas por contaminantes emergentes, tendo como norte o princípio da precaução.

Ao fim e ao cabo, a conclusão reunirá a síntese do que foi apresentado e discutido, consoante os objetivos propostos.

\footnotetext{
${ }^{16}$ HUNGRIA, Nélson. Comentários ao Código Penal. 4. ed. Rio de Janeiro: Forense, 1958. v. 1, t. 1. p. 100.

17 Acerca da importância da análise histórica: “A visão histórica consola porque retira o caráter absoluto das certezas de hoje, relativiza-as, pondo-as em fricção com certezas diferentes ou opostas experimentadas no passado, desmitifica o presente, garante que essas sejam analisadas de modo crítico, liberando os fermentos atuais da estática daquilo que é vigente e estimulando o caminho para a construção do futuro." (GROSSI, Paolo. Mitologias jurídicas da modernidade. 2. ed. rev. ampl. Tradução de Arno Dal Ri Júnior. Florianópolis, SC: Fundação Boiteaux, 2007. p. 25).
} 



\section{CONCLUSÃO}

Se o direito é de fato, como se procurou mostrar, essencialmente um fenômeno social, que surge espontaneamente a partir da formação das primeiras comunidades, derivado da necessidade de ordem inerente ao ser humano, em sua dimensão intersubjetiva, pode-se concluir que a conformação de uma nova realidade - a da crescente poluição das águas por contaminantes emergentes - conduz à construção de um novo aparato jurídico que lhe seja consentâneo, dotado de instrumentos capazes de corresponder à necessidade de ordem, tal qual ela se apresenta na sociedade pós-moderna, sob pena de instaurar-se a anomia.

A síntese histórica levada a cabo teve como escopo assinalar, portanto, como o direito surge da sociedade e evolui impulsionado - e em parte condicionado - pelo próprio desenvolvimento dela. Assim, num movimento não plenamente linear, caminhou-se de um direito uno, mais empírico do que propriamente jurídico, para o tecnicismo de um sistema altamente complexo e especializado, no qual se dá o progressivo afastamento do direito civil e penal.

Em paralelo, objetivou-se situar a questão ambiental no evoluir do direito, mostrando que embora a disciplina ambiental seja efetivamente um direito recente, a natureza e suas implicações jurídicas encontram-se presentes desde o momento em que o ser humano e seus pares estabeleceram sobre ela seu domínio, a fim de suprir suas necessidades. A apropriação e repartição do meio ambiente (suum), aposta ao pensamento antropocentrista, não obstante tenham sido sistematicamente questionados a partir da década de 1970, subsistem no direito positivo, o que obsta uma completa autonomia da tutela ambiental.

Ainda em seu âmbito, traçou-se um panorama da proteção das águas, elemento indispensável à vida no Planeta, mas que tem se tornado cada vez mais escasso, em função da interferência perniciosa do ser humano. A indisponibilidade hídrica foi analisada a partir de duas perspectivas: a qualitativa e a quantitativa, destacando-se, dos seus múltiplos fatores, a pressão pelo aumento da demanda e a poluição. 
Delimitando o conceito de poluição das águas e seus aspectos legislativos relevantes, tratou-se de investigar uma das formas mais perniciosas de poluição atualmente conhecida, a dos contaminantes que de alguma forma emergiram na sociedade pósmoderna. Procurou-se, então identificar suas características e possíveis riscos.

Em seguida, esquadrinhou-se o instituto da responsabilidade, seu desenvolvimento e as consequências que atingiram seu regime jurídico, decorrentes das transformações sociais que tiveram curso após a Revolução Industrial e que expuseram toda a sociedade sem distinção - a riscos incalculáveis.

Esse novo cenário forjado pela sociedade de risco ameaça a própria continuidade do Planeta, em particular pelo desenvolvimento do conhecimento racional e técnicocientífico com potencial autoaniquilatório (como a bomba nuclear e as armas biológicas), e pela degradação multifatorial dos elementos ambientais que dão suporte à vida.

Procurou-se mostrar que a busca de soluções jurídicas para enfrentar o cenário de incertezas fabricadas conduziu a uma incompleta proteção ambiental, que no âmbito da responsabilidade se revela na falta de articulação das esferas civil e penal, as quais buscaram compensar a limitação material com uma ampliação de suas funções, juntamente à flexibilização de suas categorias nucleares, apresentando resultados mais (direito civil) ou menos (direito penal) satisfatórios.

A despeito da indenização e da repressão permanecerem sendo funções essenciais às responsabilidades civil e penal, respectivamente, o instituto da responsabilidade foi historicamente construído sobre o princípio alterum non laedere, do qual se presume a não causação de dano.

Diante disso, e considerando os riscos potenciais que a poluição por contaminantes emergentes representam, sustentou-se a legitimidade da função preventiva.

O que se defende, portanto, é a construção de um regime coordenado das responsabilidades civil e penal para que, sob a denominação ambiental, tenha ele equilíbrio e força suficiente para assegurar uma tutela das águas em relação aos contaminantes emergentes que seja ampla e, acima de tudo, efetiva. 
Como afirmou Josserand, "temos sêde de justiça, isto é, de equilíbrio jurídico, e, quando acontece um desastre, procuramos logo o responsável; queremos que haja um responsável" ${ }^{399}$. Ocorre que, no caso dos contaminantes emergentes, ainda que se atribua responsabilidade ao ciclo de vida do poluente, do berço ao túmulo ou do berço ao berçocomo se diz na responsabilidade pelo ciclo de vida do produto nos resíduos sólidos -, não é possível eximir, em última análise, a responsabilidade de toda a humanidade, uma vez que a poluição atual é reflexo direto da sociedade pós-moderna, que assumiu o risco de sua imprudência, materializada nas ações e omissões rotineiras de cada indivíduo.

Faz-se necessário, pois, conforme sustenta Patrícia Faga Iglecias Lemos, "um sistema forte de responsabilização, de forma que seja melhor prevenir do que reparar os danos causados". 400

Para alcançar tal objetivo, defendeu-se uma leitura sistemática das responsabilidades civil e penal, buscando, na diversidade, a unidade original. A partir dessa premissa, buscou-se o prelúdio de uma responsabilidade ambiental a partir do princípio da precaução, que se torna o ponto de convergência daqueles institutos.

Uma nova responsabilidade ambiental esteia-se na adoção de um também novo substrato axiológico, que reconheça na plurissignificação da responsabilidade um necessário conteúdo ético-principiológico.

Os contaminantes emergentes, por conterem substâncias efetiva e potencialmente perigosas, capazes de produzir efeitos de relevância tanto no campo civil quanto penal, evidenciam não ser mais possível conceber os danos ambientais como questões estanques, mas sim problemas umbilicalmente afetos à condição humana.

Embora a proposta aqui apresentada implique um novel instituto de responsabilidade, ela não pressupõe a abolição dos regimes anteriores, mas apenas sua readequação, conforme o conceito negativo de justiça (alterum non laedere).

\footnotetext{
${ }^{399}$ JOSSERAND, Louis, Evolução da responsabilidade civil, cit., p. 550.

${ }^{400}$ LEMOS, Patrícia Faga Iglecias, Meio ambiente e responsabilidade civil do proprietário: análise do nexo causal, cit., p. 134.
} 
Isso significa que, no caso da poluição das águas por contaminantes emergentes, a responsabilidade deverá ser eminentemente preventiva, porquanto o risco é, ele próprio, lesivo.

Diante disso, supõe-se um plexo das responsabilidades, estabelecendo-se inicialmente, face ao risco, uma vigorosa resposta civil, preservando assim o direito penal como ultima ratio, legítimo apenas naquelas hipóteses em que, face à insuficiência ou impossibilidade da tutela civil, o risco ao direito justifique o uso da força preventiva.

A unicidade, ao estabelecer uma totalidade orgânica, garante a inexistência de contradições sistêmicas genetrizes de injustiça, ao passo que, conjugada ao princípio da precaução, garante a efetividade da responsabilidade ambiental.

Em última análise, o que se busca reconhecer é a incompatibilidade do atual regime de responsabilidade com a finalidade precípua de servir de instrumento à justiça, bem como a necessidade subsequente de superar o que parece ter-se convertido no enigma da esfinge.

O que se esboçou aqui foi um possível caminho, dentre uma infinidade de outros. Foi ele proposto, porém, a partir de uma perspectiva fenomenológica-epistemológica, fundada na constatação empírica de que, a despeito de todas as soluções apresentadas até o momento, a crise global aprofunda-se, sem dar mostras de arrefecimento.

Se há algo de certo nas incertezas da pós-modernidade, é que não há atalhos, tampouco respostas fáceis. A evolução do direito demonstrou a inegável necessidade de mudanças valorativas profundas na relação do homem com a natureza e o estabelecimento de uma nova ética para a responsabilidade, que a sociedade pós-moderna não parece disposta a aceitar.

Ao poluir o meio ambiente, e com mais razão o elemento que lhe é imprescindível, o ser humano faceia o dilema sobre sua própria existência: aceitar o destino com indolência e deixar-se ser devorado, ou tomar-lhe as rédeas, decifrando os próprios limites de sua ação, antes que seja tarde (se já assim não o for). 
Juridicamente, procurou-se demonstrar a possibilidade e a necessidade de um avanço dogmático em direção à tutela autônoma da poluição por contaminantes emergentes fundada na precaução. 



\section{REFERÊNCIAS}

ABELENDA, Virginia. El agua res commune omnium: interdictos y acciones procesales romanas en defensa de su acceso y conservación. Buenos Aires: Eudeba, 2015.

ABREU, Lígia Carvalho. A análise do risco no contexto do princípio da precaução. Lusíada. Direito e Ambiente, Lisboa, n. 1, p. 159-170, out./dez. 2008. Disponível em: $<$ http://revistas.lis.ulusiada.pt/index.php/lda/article/view/2112/2232>. Acesso em: 26 nov. 2017.

AGÊNCIA NACIONAL DE ÁGUAS (ANA). Lista de Termos para o Thesaurus de Recursos Hídricos. Brasília, 2014. Disponível em:

$<$ http://arquivos.ana.gov.br/imprensa/noticias/20150406034300_Portaria_149-2015.pdf>. Acesso em: 10 dez. 2017.

AGÊNCIA NACIONAL DE ÁGUAS (ANA); PROGRAMA DAS NAÇÕES UNIDAS PARA O MEIO AMBIENTE (PNUMA). Cuidando das águas: soluções para melhorar a qualidade dos recursos hídricos. 2. ed. Brasília, DF: ANA, 2013. Disponível em:

$<$ http://arquivos.ana.gov.br/institucional/sge/CEDOC/Catalogo/2013/CuidandoDas AguasSolucao2aEd.pdf>. Acesso em: 20 dez. 2017.

ÁGUA: um recurso cada vez mais ameaçado. Disponível em: $<$ http://www.mma.gov.br/estruturas/sedr_proecotur/_publicacao/140_publicacao0906200 9025910.pdf>. Acesso em: 10 dez. 2017.

ÁLVAREZ TORRELLAS, Silvia; GARCÍA RODRÍGUEZ, Juan; DEL RÍO GONZÁLEZ, Pedro. Evaluación del impacto medio ambiental de contaminantes emergentes: impacto medioambiental de contaminantes emergentes. Madrid: Editorial Académica Española, 2015.

ALVES FILHO, Manuel. Potável, porém contaminada. Jornal da Unicamp, Campinas, de 21 a 27 de maio de 2012, ANO 2012, n. 527, p. 3. Disponível em:

$<$ http://www.unicamp.br/unicamp/sites/default/files/jornal/paginas/pagina3A_1.pdf $>$. Acesso em: 05 out. 2017.

AMARAL, Cláudio do Prado. Despenalização pela reparação de danos: a terceira via. Leme, SP: J. H. Mizuno, 2005.

AMORIM, João Alberto Alves. Direito das águas: o regime jurídico da água doce no direito internacional e no direito brasileiro. 2. ed. rev. e ampl. São Paulo: Atlas, 2015.

ANDRADE, Manuel da Costa. A "dignidade penal" e a "carência de tutela penal" como referências de uma doutrina teleológica-racional de crime. Revista Portuguesa de Ciências Criminais, Lisboa, v. 2, p. 173- 205, 1992. Disponível em:

$<$ http://www.fd.unl.pt/docentes_docs/ma/TQB_MA_22979.pdf $>$. Acesso em: 02 out. 2017. 
ARISTÓTELES. Ética a Nicômaco. Tradução do grego de António de Castro Caeiro. São Paulo: Atlas, 2009.

ATHIAS, Jorge Alex Nunes. Responsabilidade civil e meio ambiente. In: BENJAMIN, Antônio Herman Vasconcelos e (Coord.). Dano ambiental: prevenção, reparação e repressão. São Paulo: Revista dos Tribunais, 1993. p. 237-249. (Biblioteca de Direito Ambiental, v. 2).

AYALA, Patryck de Araújo; RODRIGUES, Eveline de Magalhães Werner Rodrigues. Constitucionalismo e proteção ambiental na América Latina: é possível proteger melhor? In: CANOTILHO, José Joaquim Gomes; LEITE, José Rubens Morato (Orgs.). Direito constitucional ambiental brasileiro. 6. ed. rev. São Paulo: Saraiva, 2015. p. 476-497.

AZEVEDO, Antonio Junqueira de. O direito como sistema complexo e de $2^{\text {a }}$ ordem; sua autonomia. Ato nulo e ato ilícito. Diferença de espírito entre responsabilidade civil e penal. Necessidade de prejuízo para haver direito de indenização na responsabilidade civil (Parecer). In: 25-37. Disponível em:

$<$ https://edisciplinas.usp.br/pluginfile.php/17559/mod_resource/content/1/Estudos $\% 20 \mathrm{e} \%$ 20Pareceres\%20de\%20Direito\%20Privado\%20p.25-37.pdf>. Acesso em: 11 mar. 2017.

. O direito pós-moderno e a codificação. Revista da Faculdade de Direito, Universidade de São Paulo, São Paulo, v. 94, p. 3-12, jan. 1999. Disponível em: $<$ http://www.revistas.usp.br/rfdusp/article/view/67429>. Acesso em: 11 out. 2017.

BACIGALUPO, Enrique. Direito penal: parte geral. Tradução de André Estefam. São Paulo: Malheiros, 2005.

BAUMAN, Zygmunt. Medo líquido. Tradução de Carlos Alberto Medeiros. Rio de Janeiro: Zahar, 2008.

BENVENISTE, Emile. Le vocabulaire des institutions indo-européennes: pouvoir, droit, religion. Paris: Éditions de Minuit, 1969. v. 2. (Le Sens Commun).

BECCARIA, Cesare. Dos delitos e das penas. 6. ed. Tradução de Torrieri Guimarães. São Paulo: Martin Claret, 2014. (Coleção a obra-prima de cada autor; 48).

BECHARA, Ana Elisa Liberatore Silva. Bem jurídico-penal. São Paulo: Quartier Latin, 2014.

BECK, Ulrich. Incertezas fabricadas (Entrevista). Revista IHU ONLINE, Sociedade do risco: o medo na contemporaneidade, São Leopoldo, RS, n. 181, p. 5-12, 22 maio 2006. Disponível em: $<$ http://www.ihuonline.unisinos.br/media/pdf/IHUOnlineEdicao181.pdf $>$. Acesso em: 25 jan. 2017.

Sociedade de risco: rumo a uma outra modernidade. 2. ed., reimpr. Tradução de Sebastião Nascimento. São Paulo: Editora 34, 2013. 
BENJAMIN, Antônio Herman Vasconcelos e. Introdução ao direito ambiental brasileiro. In: CYSNE, Maurício; AMADOR, Teresa (Eds.). Direito do ambiente e redacção normativa: teoria e prática nos países lusófonos. Gland, Suíça; Cambridge, Reino Unido; Bona, Alemanha: UICN, 2000. p. 31-78. (Estudo de Política e Direito do Ambiente da UICN, n. 42).

. Responsabilidade civil pelo dano ambiental. In: MILARÉ, Édis; MACHADO, Paulo Affonso Leme (Orgs.). Direito ambiental: responsabilidade em matéria ambiental. São Paulo: Revista dos Tribunais, 2011. p. 75-136. (Coleção Doutrinas Essenciais. Direito Ambiental, v. 5).

BENJAMIN, Antônio Herman Vasconcelos e (Coord.). Dano ambiental: prevenção, reparação e repressão. São Paulo: Revista dos Tribunais, 1993. (Biblioteca de Direito Ambiental, v. 2).

BETIOL, Luciana Stocco. Responsabilidade civil e proteção ao meio ambiente. São Paulo: Saraiva, 2010.

BÍBLIA Sagrada. Disponível em: $<$ http://www.paroquias.org/biblia/?c=Gn+1 $>$. Acesso em: 10 maio 2017.

BILA, Daniele Maia; DEZOTTI, Márcia. Desreguladores endócrinos no meio ambiente: efeitos e consequências. Química Nova, São Paulo, v. 30, n. 3, p. 651-666, 2007. Disponível em: $<$ http://quimicanova.sbq.org.br/imagebank/pdf/Vol30No3_651_26RV06127.pdf>. Acesso em: 30 jun. 2017.

BITTAR, Eduardo Carlos Bianca. A justiça em Aristóteles. 2. ed. Rio de Janeiro: Forense Universitária, 2001.

. Metodologia da pesquisa jurídica. 14. ed. São Paulo: Saraiva, 2016.

BLANCO LOZANO, Carlos. La tutela del agua a través del derecho penal. Barcelona: Jose Maria Bosch, 2000.

BOBBIO, Norberto. A era dos direitos. Tradução de Carlos Nelson Coutinho. Rio de Janeiro: Elsevier, 2004.

. Teoria do ordenamento jurídico. Tradução de Ari Marcelo Solon. São Paulo: Edipro, 2011.

BOMBARDI, Larissa Mies. Geografia do uso de agrotóxicos no Brasil e conexões com a União Europeia. São Paulo: FFLCH-USP, 2017. Disponível em:

$<$ https://goo.gl/4XY3SS $>$. Acesso em: 20 dez. 2017.

BORGES-DUARTE, Irene. O homem como fim em si?: de Kant a Heidegger e Jonas. Revista Portuguesa de Filosofia, v. 61, n. 3/4, p. 841-862, 2005. Disponível em: $<w w w . j s t o r . o r g / s t a b l e / 40338193>$. Acesso em: 09 set. 2017. 
BOTTINI, Pierpaolo Cruz. Crimes de perigo abstrato. 3. ed. rev., atual. e ampl. São Paulo: Revista dos Tribunais, 2013.

BRASIL. Constituição da República Federativa do Brasil de 1988. Disponível em: $<$ http://www.planalto.gov.br/ccivil_03/constituicao/constituicaocompilado.htm>. Acesso em: 30 nov. 2017.

BRASIL. Decreto $n^{\circ} 847$, de 11 de outubro de 1890. Promulga o Codigo Penal. Disponível em: <http://www.planalto.gov.br/ccivil_03/decreto/1851-1899/d847.htm>. Acesso em: 10 dez. 2017.

BRASIL. Decreto n ${ }^{\circ} 2.519$, de 16 de março de 1998. Promulga a Convenção sobre Diversidade Biológica, assinada no Rio de Janeiro, em 05 de junho de 1992. Disponível em: <http://www.planalto.gov.br/ccivil_03/decreto/d2519.htm>. Acesso em: 20 dez. 2017.

BRASIL. Decreto ${ }^{\circ} 2.652$, de $1^{\circ}$ de julho de 1998. Aprova o texto do Convenção-Quadro das Nações Unidas sobre Mudança do Clima, adotada em Nova Iorque, em 9 de maio de 1992. Disponível em: <http://www.planalto.gov.br/ccivil_03/decreto/d2652.htm>. Acesso em: 20 dez. 2017.

BRASIL. Decreto no 2.848 , de 7 de dezembro de 1940. Código Penal. Disponível em: $<$ http://www.planalto.gov.br/ccivil_03/decreto-lei/Del2848compilado.htm>. Acesso em: 30 nov. 2017.

BRASIL. Decreto $\mathrm{n}^{\circ} 4.074$, de 04 de janeiro de 2002. Regulamenta a Lei $\mathrm{n}^{\mathrm{o}} 7.802$, de 11 de julho de 1989, que dispõe sobre a pesquisa, a experimentação, a produção, a embalagem e rotulagem, o transporte, o armazenamento, a comercialização, a propaganda comercial, a utilização, a importação, a exportação, o destino final dos resíduos e embalagens, o registro, a classificação, o controle, a inspeção e a fiscalização de agrotóxicos, seus componentes e afins, e dá outras providências. Disponível em: $<$ http://www.planalto.gov.br/ccivil_03/decreto/2002/d4074.htm>. Acesso em: $10 \mathrm{dez}$. 2017.

BRASIL. Decreto $\mathrm{n}^{\circ} 5.300$, de 7 de dezembro de 2004. Regulamenta a Lei $\mathrm{n}^{\circ} 7.661$, de 16 de maio de 1988, que institui o Plano Nacional de Gerenciamento Costeiro - PNGC, dispõe sobre regras de uso e ocupação da zona costeira e estabelece critérios de gestão da orla marítima, e dá outras providências. Disponível em:

$<$ http://www.planalto.gov.br/ccivil_03/_ato2004-2006/2004/decreto/d5300.htm>. Acesso em: 17 dez. 2017.

BRASIL. Decreto ${ }^{\circ} 5.440$, de 4 de maio de 2005. Estabelece definições e procedimentos sobre o controle de qualidade da água de sistemas de abastecimento e institui mecanismos e instrumentos para divulgação de informação ao consumidor sobre a qualidade da água para consumo humano. Disponível em: <http://www.planalto.gov.br/ccivil_03/_ato20042006/2005/decreto/d5440.htm>. Acesso em: 10 dez. 2017.

BRASIL. Decreto $n^{\circ} 5.472$, de 20 de junho de 2005. Promulga o texto da Convenção de Estocolmo sobre Poluentes Orgânicos Persistentes, adotada, naquela cidade, em 22 de maio de 2001. Disponível em: <http://www.planalto.gov.br/ccivil_03/_ato20042006/2005/decreto/d5472.htm>. Acesso em: 10 dez. 2017. 
BRASIL. Decreto $n^{0} 7.217$, de 21 de junho de 2010. Regulamenta a Lei $n^{\circ} 11.445$, de 5 de janeiro de 2007, que estabelece diretrizes nacionais para o saneamento básico, e dá outras providências. Disponível em: <http://www.planalto.gov.br/ccivil_03/_ato20072010/2010/decreto/d7217.htm>. Acesso em: 10 dez. 2017.

BRASIL. Decreto n ${ }^{\circ} 23.672$, de 2 de janeiro de 1934. Approva o Codigo de Caça e Pesca que com este baixa. Disponível em: $<$ https://www.planalto.gov.br/ccivil_03/decreto/19301949/D23672.htm>. Acesso em: 10 dez. 2017.

BRASIL. Decreto no 24.643, de 10 de julho de 1934. Decreta o Código de Águas. Disponível em: < http://www.planalto.gov.br/ccivil_03/decreto/d24643.htm>. Acesso em: 10 dez. 2017.

BRASIL. Decreto n ${ }^{\circ} 50.877$, de 29 de junho de 1961. Dispõe sôbre o lançamento de resíduos tóxicos ou oleosos nas águas interiores ou litorâneas do País, e dá outras providências. Disponível em: <http://www2.camara.leg.br/legin/fed/decret/19601969/decreto-50877-29-junho-1961-390520-publicacaooriginal-1-pe.html>. Acesso em: 10 dez. 2017.

BRASIL. Decreto $\mathrm{n}^{\circ} 73.030$, de 30 de outubro de 1973. Cria, no âmbito do Ministério do Interior, a Secretaria Especial do Meio Ambiente - SEMA, e da outras providências. Disponível em: < http://www2.camara.leg.br/legin/fed/decret/1970-1979/decreto-7303030-outubro-1973-421650-publicacaooriginal-1-pe.html>. Acesso em: 10 dez. 2017.

BRASIL. Decreto ${ }^{\circ} 76.389$, de 3 de outubro de 1975. Dispõe sobre as medidas de prevenção e controle da poluição industrial, de que trata o Decreto-Lei n ${ }^{\circ} 1.413$, de 14 de agosto de 1975, e dá outras providências. Disponível em:

$<$ http://www2.camara.leg.br/legin/fed/decret/1970-1979/decreto-76389-3-outubro-1975424990-publicacaooriginal-1-pe.html>. Acesso em: 10 dez. 2017.

BRASIL. Decreto Legislativo ${ }^{\circ}{ }^{1}$, de 1994. Aprova o texto do Convenção-Quadro das Nações Unidas sobre Mudança do Clima, adotada em Nova Iorque, em 9 de maio de 1992. Disponível em: <http://www2.camara.leg.br/legin/fed/decleg/1994/decretolegislativo-1-3fevereiro-1994-358285-publicacaooriginal-1-pl.html>. Acesso em: 20 dez. 2017.

BRASIL. Decreto Legislativo $\mathrm{n}^{\circ}$ 2, de 3 de fevereiro de 1994. Aprova o texto da Convenção sobre Diversidade Biológica, assinada durante a Conferência das Nações Unidas sobre Meio Ambiente e Desenvolvimento, realizada na Cidade do Rio de Janeiro, no período de 5 a 14 de junho de 1992. Disponível em:

$<$ http://www2.camara.leg.br/legin/fed/decleg/1994/decretolegislativo-2-3-fevereiro-1994358280-publicacaooriginal-1-pl.html>. Acesso em: 20 dez. 2017.

BRASIL. Decreto-Lei no 221, de 28 de fevereiro de 1967. Dispõe sôbre a proteção e estímulos à pesca e dá outras providências. Disponível em:

$<$ http://www.planalto.gov.br/ccivil_03/decreto-lei/Del0221.htm>. Acesso em: $10 \mathrm{dez}$. 2017.

BRASIL. Decreto-Lei no 303, de 28 de fevereiro de 1967. Cria o Conselho Nacional de Contrôle da Poluição Ambiental e dá outras providências. Disponível em: $<$ http://www.planalto.gov.br/ccivil_03/decreto-lei/1965-1988/Del0303.htm>. Acesso em: 10 dez. 2017. 
BRASIL. Decreto-Lei no 794, de 19 de outubro de 1938. Aprova e baixa o Código de Pesca. Disponível em: <https://www.planalto.gov.br/ccivil_03/Decreto-Lei/19371946/Del0794.htm\#art2.>. Acesso em: 10 dez. 2017.

BRASIL. Decreto-Lei $n^{0} 1.413$, de 31 de julho de 1975. Dispõe sobre o controle da poluição do meio ambiente provocada por atividades industriais. Disponível em: $<$ http://www.planalto.gov.br/ccivil_03/decreto-lei/1965-1988/Del1413.htm>. Acesso em: 10 dez. 2017.

BRASIL. Lei $\mathrm{n}^{0}$ 5.318, de 26 de setembro e 1967. Institui a Política Nacional de Saneamento e cria o Conselho Nacional de Saneamento. Disponível em: $<$ http://www.planalto.gov.br/ccivil_03/LEIS/1950-1969/L5318.htm\#art13>. Acesso em: 10 dez. 2017.

BRASIL. Lei ${ }^{\circ}$ 6.453, de 17 de outubro de 1977. Dispõe sobre a responsabilidade civil por danos nucleares e a responsabilidade criminal por atos relacionados com atividades nucleares e dá outras providências. Disponível em: $<$ http://www.planalto.gov.br/ccivil_03/leis/L6453.htm>. Acesso em: 16 dez. 2017.

BRASIL. Lei n 6.938 , de 31 de agosto de 1981. Dispõe sobre a Política Nacional do Meio Ambiente, seus fins e mecanismos de formulação e aplicação, e dá outras providências. Disponível em: <http://www.planalto.gov.br/ccivil_03/leis/L6938.htm>. Acesso em: 30 nov. 2017.

BRASIL. Lei no 8.078, de 11 de setembro de 1990. Dispõe sobre a proteção do consumidor e dá outras providências. Disponível em:

$<$ http://www.planalto.gov.br/ccivil_03/leis/L8078.htm>. Acesso em: 30 nov. 2017.

BRASIL. Lei no 8.080, de 19 de setembro de 1990. Dispõe sobre as condições para a promoção, proteção e recuperação da saúde, a organização e o funcionamento dos serviços correspondentes e dá outras providências. Disponível em:

$<$ http://www.planalto.gov.br/ccivil_03/leis/L8080.htm>. Acesso em: 10 dez. 2017.

BRASIL. Lei ${ }^{\circ}$ 9.433, de 8 de janeiro de 1997. Institui a Política Nacional de Recursos Hídricos, cria o Sistema Nacional de Gerenciamento de Recursos Hídricos, regulamenta o inciso XIX do art. 21 da Constituição Federal, e altera o art. $1^{\circ}$ da Lei $n^{\circ} 8.001$, de 13 de março de 1990, que modificou a Lei no 7.990, de 28 de dezembro de 1989. Disponível em: $<$ http://www.planalto.gov.br/ccivil_03/leis/L9433.htm>. Acesso em: 10 dez. 2017.

BRASIL. Lei $\mathrm{n}^{\circ}$ 9.605, de 12 de fevereiro de 1998. Dispõe sobre as sanções penais e administrativas derivadas de condutas e atividades lesivas ao meio ambiente, e dá outras providências. Disponível em: <http://www.planalto.gov.br/ccivil_03/leis/L9605.htm>. Acesso em: 10 dez. 2017.

BRASIL. Lei n ${ }^{\circ} 10.406$, de 10 de janeiro de 2002. Institui o Código Civil. Disponível em: $<$ http://www.planalto.gov.br/ccivil_03/leis/2002/L10406compilada.htm>. Acesso em: 30 nov. 2017. 
BRASIL. Lei $\mathrm{n}^{\circ} 11.105$, de 24 de março de 2005. Regulamenta os incisos II, IV e V do $\S$ $1^{\circ}$ do art. 225 da Constituição Federal, estabelece normas de segurança e mecanismos de fiscalização de atividades que envolvam organismos geneticamente modificados - OGM e seus derivados, cria o Conselho Nacional de Biossegurança - CNBS, reestrutura a Comissão Técnica Nacional de Biossegurança - CTNBio, dispõe sobre a Política Nacional de Biossegurança - PNB, revoga a Lei $n^{\circ}$ 8.974, de 5 de janeiro de 1995, e a Medida Provisória $n^{\circ} 2.191-9$, de 23 de agosto de 2001 , e os arts. $5^{\circ}, 6^{\circ}, 7^{\circ}, 8^{\circ}, 9^{\circ}, 10$ e 16 da Lei $n^{\circ}$ 10.814, de 15 de dezembro de 2003, e dá outras providências. Disponível em:

$<$ http://www.planalto.gov.br/ccivil_03/_ato2004-2006/2005/lei/111105.htm>. Acesso em: 17 dez. 2017.

BRASIL. Lei n ${ }^{\text {1 }}$ 11.936, de 14 de maio de 2009. Proíbe a fabricação, a importação, a exportação, a manutenção em estoque, a comercialização e o uso de diclorodifeniltricloretano (DDT) e dá outras providências. Disponível em: $<$ http://www.planalto.gov.br/ccivil_03/_ato2007-2010/2009/Lei/L11936.htm>. Acesso em: 30 nov. 2017.

BRASIL. Lei ${ }^{\circ}$ 12.187, de 29 de dezembro de 2009. Institui a Política Nacional sobre Mudança do Clima - PNMC e dá outras providências. Disponível em:

$<$ http://www.planalto.gov.br/ccivil_03/_ato2007-2010/2009/lei/112187.htm>. Acesso em: 17 dez. 2017.

BRASIL. Lei $\mathrm{n}^{\circ}$ 12.305, de 02 de agosto de 2010. Institui a Política Nacional de Resíduos Sólidos; altera a Lei ${ }^{\circ}$ 9.605, de 12 de fevereiro de 1998; e dá outras providências.

Disponível em: <http://www.planalto.gov.br/ccivil_03/_ato20072010/2010/lei/112305.htm>. Acesso em: 17 dez. 2017.

BRASIL. Lei n ${ }^{\circ}$ 12. 608, e 10 de abril de 2012. Institui a Política Nacional de Proteção e Defesa Civil - PNPDEC; dispõe sobre o Sistema Nacional de Proteção e Defesa Civil SINPDEC e o Conselho Nacional de Proteção e Defesa Civil - CONPDEC; autoriza a criação de sistema de informações e monitoramento de desastres; altera as Leis nos 12.340 , de $1^{\circ}$ de dezembro de 2010, 10.257, de 10 de julho de 2001, 6.766, de 19 de dezembro de 1979, 8.239, de 4 de outubro de 1991, e 9.394, de 20 de dezembro de 1996; e dá outras providências. Disponível em: $<$ http://www.planalto.gov.br/ccivil_03/_ato20112014/2012/lei/112608.htm>. Acesso em: 17 dez. 2017.

BRASIL. Ministério da Agricultura, Pecuária e Abastecimento Gabinete do Ministro. Portaria $\mathrm{n}^{\mathrm{o}} 329$, de 02 de setembro de 1985. Disponível em:

$<$ http://bvsms.saude.gov.br/bvs/saudelegis/mapa_gm/1985/prt0329_02_09_1985.html>. Acesso em: 10 dez. 2017.

BRASIL. Ministério das Cidades. Secretaria Nacional de Saneamento Ambiental (SNSA). Sistema Nacional de Informações sobre Saneamento (SNIS). Diagnóstico dos serviços de água e esgotos: 2015. Brasília: SNSA/MCIDADES, 2017. Disponível em:

$<$ http://www.snis.gov.br/diagnostico-agua-e-esgotos/diagnostico-ae-2015>. Acesso em: 10 dez. 2017. 
BRASIL. Ministério do Meio Ambiente. Conselho Nacional de Meio Ambiente.

Resolução Conama n ${ }^{\circ}$ 357, de 17 de março de 2005. Alterada pela Resolução 410/2009 e pela 430/2011. Dispõe sobre a classificação dos corpos de água e diretrizes ambientais para o seu enquadramento, bem como estabelece as condições e padrões de lançamento de efluentes, e dá outras providências.

$<$ http://www.mma.gov.br/port/conama/legiabre.cfm?codlegi=459>. Acesso em: $10 \mathrm{dez}$. 2017.

BRASIL. Ministério do Meio Ambiente. Conselho Nacional de Meio Ambiente.

Resolução CONAMA n ${ }^{\circ} 420$, de 28 de dezembro de 2009. Dispõe sobre critérios e valores orientadores de qualidade do solo quanto à presença de substâncias químicas e estabelece diretrizes para o gerenciamento ambiental de áreas contaminadas por essas substâncias em decorrência de atividades antrópicas. Disponível em:

$<$ http://www.mma.gov.br/port/conama/legiabre.cfm?codlegi=620>. Acesso em: $10 \mathrm{dez}$. 2017.

BRASIL. Ministério do Meio Ambiente. Conselho Nacional de Meio Ambiente.

Resolução Conama ${ }^{\circ} 430$, de 13 de maio de 2011. Complementa e altera a Resolução $n^{\circ}$ 357/2005. Dispõe sobre as condições e padrões de lançamento de efluentes, complementa e altera a Resolução no 357, de 17 de março de 2005, do Conselho Nacional do Meio Ambiente-CONAMA. Disponível em:

$<$ http://www.mma.gov.br/port/conama/legiabre.cfm?codlegi=646>. Acesso em: $10 \mathrm{dez}$. 2017.

BRASIL. Ministério da Saúde. Portaria n. 2.914, de 12 de dezembro de 2011. Dispõe sobre os procedimentos de controle e de vigilância da qualidade da água para consumo humano e seu padrão de potabilidade. Disponível em:

$<$ http://bvsms.saude.gov.br/bvs/saudelegis/gm/2011/prt2914_12_12_2011.html $>$. Acesso em: 10 dez. 2017.

BRENNAN, Andrew; LO, Yeuk-Sze. Environmental ethics. In: The Stanford Encyclopedia of Philosophy. (Winter 2016 edition), Edward N. Zalta (Ed.). Disponível em: $<$ https://plato.stanford.edu/archives/win2016/entries/ethics-environmental/>. Acesso em: 25 jan. 2017.

BRITO, Alexis Couto de. Imputação e direito penal brasileiro. In: SILVEIRA, Renato de Mello Jorge; SALVADOR NETTO, Alamiro Velludo; SOUZA, Luciano Anderson de (Coords.). Direito penal na pós-modernidade: escritos em homenagem a Antonio Luis Chaves de Camargo. São Paulo: Quartier Latin, 2015. p. 55-79.

BRÜSEKE, Franz Josef. Risco e contingência. Revista Brasileira de Ciências Sociais, São Paulo, v. 22, n. 63, p. 69-80, fev. 2007. Disponível em:

$<$ http://www.scielo.br/scielo.php?script=sci_arttext\&pid=S0102-

69092007000100006\&lng=en\&nrm=iso>. Acesso em: 16 set. 2017.

CAMARGO, Antonio Luis Chaves de. Imputação objetiva e direito penal brasileiro. São Paulo: Cultural Paulista, 2002. 
CAMARGO, Beatriz Corrêa. O finalismo no direito penal brasileiro: uma abordagem crítica da ciência jurídico-penal no Brasil. In: SILVEIRA, Renato de Mello Jorge; SALVADOR NETTO, Alamiro Velludo; SOUZA, Luciano Anderson de (Coords.). Direito penal na pós-modernidade: escritos em homenagem a Antonio Luis Chaves de Camargo. São Paulo: Quartier Latin, 2015. p. 81-122.

CAMPOS, Aline da Veiga Cabral. Precaução ambiental na era do direito penal secundário. In: D’ÁVILA, Fabio Roberto; SOUZA, Paulo Vinicius Sporleder de (Coords.). Direito penal secundário: estudos sobre crimes econômicos, ambientais, informáticos e outras questões. São Paulo: Revista dos Tribunais; Coimbra: Coimbra Editora, 2006. p. 97-112.

CANELA, Maria Cristina et al. (Eds.). Cafeína em águas de abastecimento público no Brasil. São Carlos: Editora Cubo, 2014.

CANOTILHO, José Joaquim Gomes Gomes. Direito constitucional e teoria da constituição. 7. ed., 14. reimpr. Coimbra: Almedina, 2013.

CANOTILHO, José Joaquim Gomes; LEITE, José Rubens Morato (Orgs.). Direito constitucional ambiental brasileiro. 6. ed. rev. São Paulo: Saraiva, 2015.

CARNELUTTI, Francesco. Como nasce o direito. Tradução de Roger Vinícius da Silva Costa. São Paulo: Editora Pillares, 2015.

CARSON, Rachel. Primavera silenciosa. Tradução de Claudia Sant'Anna Martins. São Paulo: Gaia, 2010.

CARVALHO, Délton Winter de. A formação sistêmica do sentido jurídico de meio ambiente. Lusiada. Direito e Ambiente, Lisboa, n. 1, p. 55-70, 2008. Disponível em: $<$ http://revistas.lis.ulusiada.pt/index.php/lda/article/view/2107/2227>. Acesso em: 26 nov. 2017.

- A teoria do dano ambiental futuro: a responsabilização civil por riscos ambientais. Lusíada. Direito e Ambiente, Lisboa, n. 1, p. 71-105, 2008. Disponível em: $<$ http://revistas.lis.ulusiada.pt/index.php/lda/article/view/2108/2228>. Acesso em: 26 nov. 2017.

CAVALIERI FILHO, Sergio. Programa de responsabilidade civil. 12. ed. rev. e ampl. São Paulo: Atlas, 2015.

CHABAS, François. Responsabilité civile et responsabilité pénale. Paris: Éditions Montchrestien, 1975.

CHAVES, Antônio. Poluição e responsabilidade no direito brasileiro. In: MILARÉ, Édis; MACHADO, Paulo Affonso Leme (Orgs.). Direito ambiental: responsabilidade em matéria ambiental. São Paulo: Revista dos Tribunais, 2011. p. 621-645. (Coleção Doutrinas Essenciais. Direito Ambiental, v. 5).

CHEVALIER, Jean; GHEERBRANT, Alain. Diccionario de los símbolos. Barcelona: Herder, 1986. 
CICERO, Marcus Tullius. Pro Sulla (45). In: Orationes VI: pro Sulla, pro Sextio, pro Milone, pro Archia p., pro Ligario et pro rege Deiotaro. Lipsiae: F. Vogel, 1830.

COMMETTI, Filipe Domingos; VENDRAMINI, Sylvia Maria Machado; GUERRA, Roberta Freitas. O desenvolvimento do direito das águas como um ramo autônomo da ciência jurídica brasileira. In: MILARÉ, Édis; MACHADO, Paulo Affonso Leme (Orgs.). Direito ambiental: conservação e degradação do meio ambiental. São Paulo: Revista dos Tribunais, 2011. p. 157-214. (Coleção Doutrinas Essenciais. Direito Ambiental, v. 2).

COMPANHIA AMBIENTAL DO ESTADO DE SÃO PAULO (CETESB). Procedimento para estabelecer e utilizar os valores orientadores para solo e água subterrânea (Manual Técnico). Setembro de 2007. Disponível em:

$<$ http://www.mma.gov.br/port/conama/processos/FE4582B1/NormaCETESBVO.pdf $>$. Acesso em: 10 dez. 2017.

CONTAMINANTES emergentes. [Entrevistas com Josino Costa Moreira, Eline Simões Gonçalves e Magda Beretta]. RQI, Revista de Química Industrial, Rio de Janeiro, n. 738, p. 4-13, 2013. Disponível em: <http://www.abq.org.br/rqi/2013/738/RQI-738-pagina4Contaminantes-Emergentes.pdf>. Acesso em: $10 \mathrm{dez} .2017$.

CORCORAN, Emily et al. (Eds.). Sick water?: the central role of waste-water management in sustainable development: a rapid response assessment. Arendal, Norway: United Nations Environment Programme UNEP/GRID-Arendal; Nairobi, Kenya: UNHABITAT, GRID-Arendal, 2010. Disponível em: $<$ https://gridarendalwebsite.s3.amazonaws.com/production/documents/:s_document/208/original/SickWater_s creen.pdf?1486721310>. Acesso em: 09 out. 2017.

CORPUS IURIS CIVILIS. Lyon: Hugues de la Porte, 1558-1560. Versão digitalizada disponível em: <http://amshistorica.unibo.it/176\#>. Acesso em: 27 fev. 2017.

COSTA, José Francisco de Faria. O perigo em direito penal: contributo para a sua fundamentação e compreensão dogmáticas. Reimpr. Coimbra: Coimbra Editora, 2000.

COSTA JÚNIOR, Paulo José da. Nexo causal. 2. ed. São Paulo: Saraiva, 1996.

CRUZ, Branca Maria Pereira da Silva Martins. Desenvolvimento sustentável e responsabilidade ambiental. Lusíada. Direito e Ambiente, Lisboa, n. 1, p. 9-53, out./dez. 2008. Disponível em:

$<$ http://revistas.lis.ulusiada.pt/index.php/lda/article/view/2106/2226>. Acesso em: 26 nov. 2017.

CRUZ, Gisela Sampaio da. O problema do nexo causal na responsabilidade civil. Rio de Janeiro: Renovar, 2005.

DALLARI, Dalmo de Abreu. Elementos de teoria geral do estado. 30. ed. São Paulo: Saraiva, 2011.

D’ÁVILA, Fabio Roberto; SOUZA, Paulo Vinicius Sporleder de (Coords.). Direito penal secundário: estudos sobre crimes econômicos, ambientais, informáticos e outras questões. São Paulo: Revista dos Tribunais; Coimbra: Coimbra Editora, 2006. 
DELILE, Hugo et al. Lead in ancient Rome's city waters. PNAS, Proceedings of the National Academy of Sciences of the United States of America, v. 111, No. 18, p. 6.5946.599, 2014. Disponível em: <http://www.pnas.org/content/111/18/6594.full.pdf $>$. Acesso em: 10 dez. 2017.

DEL MASTRO, André Menezes. A função punitivo-preventiva da responsabilidade civil. Revista da Faculdade de Direito da Universidade de São Paulo, São Paulo, v. 110, p. 765-817, maio 2016. Disponível em:

$<$ http://www.revistas.usp.br/rfdusp/article/view/115511/113092>. Acesso em: $01 \mathrm{dez}$. 2017.

DIAS, José de Aguiar. Da responsabilidade civil. 12. ed. rev. atual. de acordo com o Código Civil de 2002, 2. tiragem aumentada por Rui Berford Dias. Rio de Janeiro: Lumen Juris, 2012.

DOTTI, René Ariel. Meio ambiente e proteção penal. In: MILARÉ, Édis; MACHADO, Paulo Affonso Leme (Orgs.). Direito ambiental: responsabilidade em matéria ambiental. São Paulo: Revista dos Tribunais, 2011. p. 1.253-1.274. (Coleção Doutrinas Essenciais. Direito Ambiental, v. 5).

ENDOCRINE disruption: what is endocrine disruption? Disponível em: $<$ https://www.epa.gov/endocrine-disruption/what-endocrine-disruption $>$. Acesso em: 10 dez. 2017.

ESTADO do meio ambiente e retrospectivas políticas: 1972-2002: água doce. In: PROGRAMA DAS NAÇÕES UNIDAS PARA MEIO AMBIENTE (PNUMA). Perspectivas do meio ambiente mundial 2002 GEO-3: passado, presente e futuro. Brasília: IBAMA/PNUMA, 2004. Cap. 2, p. 162-197. Disponível em:

$<$ http://www.wwiuma.org.br/geo_mundial_arquivos/cap2_\%20aguadoce.pdf $>$. Acesso em 20 maio 2017.

EWALD, François. Le retour du malin genie: esquisse d'une philosophie de la précaution. In: GODARD, Olivier (Dir.). Le principe de précaution: dans la conduite des affaires humaines. Paris: Maison des Sciences de l'Homme; Institut national de la recherche agronomique (INRA), 1997. p. 99-126.

FABIANI, Jean-Louis. Principe de précaution et protection de la nature. In: GODARD, Olivier (Dir.). Le principe de précaution: dans la conduite des affaires humaines. Paris: Maison des Sciences de l'Homme; Institut national de la recherche agronomique (INRA), 1997. p. 297-309.

FACHIN, Luiz Edson. Responsabilidade civil contemporânea no Brasil: notas para uma aproximação. Revista Jurídica, Porto Alegre, RS, v. 58, n. 397, p. 11-20, nov. 2010.

FEATURE: UN's mission to keep plastics out of oceans and marine life. UN News Centre, 27 de abril de 2017. Disponível em:

$<$ http://www.un.org/sustainabledevelopment/blog/2017/04/feature-uns-mission-to-keepplastics-out-of-oceans-and-marine-life/>. Acesso em: 14 out. 2017. 
FERRAJOLI, Luigi. Direito e razão: teoria do garantismo penal. Tradução de Ana Paula Zomer et al. São Paulo: Revista dos Tribunais, 2002.

FERRAZ, Esther de Figueiredo. O crime de poluição de água potável. In: DI FRANCESCO, José Roberto Pacheco (Org.). Estudos em homenagem ao professor Sílvio Rodrigues. São Paulo: Saraiva, 1989. p. 105-128.

FERRAZ JUNIOR, Tercio Sampaio. A ciência do direito. 3. ed. São Paulo: Atlas, 2014. . Introdução ao estudo do direito: técnica, decisão, dominação. 4. ed. rev. e ampl São Paulo: Atlas, 2003.

FERREIRA, Ivette Senise. Poluição e tutela ambiental. Revista da Faculdade de Direito da Universidade de São Paulo, São Paulo, v. 93, p. 249-288, jan. 1998. Disponível em: $<$ http://www.revistas.usp.br/rfdusp/article/view/67405/70015>. Acesso em: 10 dez. 2017.

FRAGOSO, Heleno Cláudio. Lições de direito penal: parte geral. 16. ed. atualizada por Fernando Fragoso. Rio de Janeiro: Forense, 2003.

FIGUEIREDO, Guilherme Gouvêa de. Crimes ambientais à luz do conceito de bem jurídico-penal: (des)criminalização, redação típica e (in)ofensividade. São Paulo: IBCCRIM, 2008. (Monografias científicas, 47).

FREITAS, Gilberto Passos de. A tutela penal do meio ambiente. In: BENJAMIN, Antônio Herman Vasconcelos e (Coord.). Dano ambiental: prevenção, reparação e repressão. São Paulo: Revista dos Tribunais, 1993. p. 308-318. (Biblioteca de Direito Ambiental, v. 2).

FREITAS, Juarez. A interpretação sistemática do direito. 3. ed. rev. e ampl. São Paulo: Malheiros, 2002.

FRIEDMAN, Lawrence M. Coming of age: law and society enters an exclusive club. Annual Review of Law and Social Science, v. 1, p. 1-16, Dec. 2005. Disponível em: $<$ http://www.annualreviews.org/doi/abs/10.1146/annurev.lawsocsci.1.041604.115951>. Acesso em: 19 jun. 2017.

FRIEDRICH, Carl Joachim. La fisolofía del derecho. Traducción del aleman por Margarita Álvarez Franco. México: Fondo de Cultura Economica (FCE), 1964.

GANDIN, Magali. Le principe de précaution: nouveau fondement de responsabilité civile? Paris: Éditions Universitaire Européenne, 2014.

GARCÍA PÉREZ, Carmen L. Aspectos civiles del delito de usurpación de aguas. In: PERES RIERA, Jaime Miguel (Dir.); CUESTA PASTOR, Pablo (Coord.) La tutela penal del agua. Madrid: Dykinson, 2009. p. 213-272.

GARDIN-DUMESNIL, Jean Baptiste. Latin synonyms, with their different significations, and examples taken from the best latin authors. Translated into English, with additions and corrections, by J. M. Gosset. London: Richard Taylor, 1809. 
GASTALDI, Viviana. Direito penal na Grécia antiga. Tradução de Mônica Sol Glik. Florianópolis, SC: Fundação Boiteux, 2006. (Coleção Arqueologia Jurídica).

GHISELLI, Gislaine; JARDIM, Wilson F. Interferentes endócrinos no ambiente. Química Nova, São Paulo, v. 30, n. 3, p. 695-706, maio/jun. 2007. Disponível em:

$<$ http://www.scielo.br/pdf/qn/v30n3/31.pdf>. Acesso em: 09 out. 2017.

GIDDENS, Anthony. As consequências da modernidade. 5. reimpr. Tradução de Raul Fiker. São Paulo: Editora Unesp, 1991.

. Mundo em descontrole: o que a globalização está fazendo de nós. Tradução de Maria Luiza X. de A. Borges. 6. ed. Rio de Janeiro: Record, 2007.

GIL, Miriam Janet et al. Contaminantes emergentes en aguas, efectos y posibles tratamentos. Producción + Limpia, Caldas, Antioquia, Colômbia, Corporación Universitaria Lasallista v. 7, n. 2, p. 52-73, jul./dic. 2012. Disponível em:

$<$ http://www.scielo.org.co/pdf/pml/v7n2/v7n2a05.pdf>. Acesso em: 13 abr. 2017.

GILISSEN, John. Introdução histórica ao direito. 8. ed. Tradução de António Manuel Hespanha e Manuel Luís Macaísta Malheiros. Lisboa: Calouste Gulbenkian, 2016.

GIMÉNEZ ALCOVER, Pilar. El derecho en la teoría de la sociedad de Niklas Luhmann. Barcelona: J. M. Bosch, 1993.

GODARD, Olivier. L'ambivalence de la précaution et la transformation des rapports entre science et décision. In: GODARD, Olivier (Dir.). Le principe de précaution: dans la conduite des affaires humaines. Paris: Maison des Sciences de l'Homme; Institut national de la recherche agronomique (INRA), 1997. p. 37-83.

. The precautionary principle and chemical risks. Ecole Polytechnique. Centre National de la Recherche Scientifique. January 2012. Cahier $n^{\circ}$ 2012-17. Disponível em: $<$ https://hal.archives-ouvertes.fr/hal-00689761/document.>. Acesso em: 10 nov. 2017.

GODOY, Claudio Luiz Bueno de. Responsabilidade civil pelo risco da atividade: uma cláusula geral no Código Civil de 2002. 2. ed. São Paulo: Saraiva, 2010. (Coleção Professor Agostinho Alvim).

GOMES, Orlando. Introdução ao direito civil. Rio de Janeiro: Forense, 1957.

. Tendências modernas na teoria da responsabilidade civil. In: DI FRANCESCO, José Roberto Pacheco (Org.). Estudos em homenagem ao professor Sílvio Rodrigues. São Paulo: Saraiva, 1989. p. 291-302.

GORMAN, Joseph A. Drugs in our water: a legal proposal for responsible nationwide pharmaceutical consumption. Journal of Land Use \& Environmental Law, Tallahassee, Florida, v. 26, No. 1, p. 147-178, Fall 2010. Disponível em:

$<$ http://www.jstor.org/stable/42842915>. Acesso em: 10 nov. 2017. 
GROSSI, Paolo. Mitologias jurídicas da modernidade. 2. ed. rev. ampl. Tradução de Arno Dal Ri Júnior. Florianópolis, SC: Fundação Boiteaux, 2007.

GROTZINGER, John; JORDAN, Tom. Para entender a Terra. Tradução de Iuri Duquia Abreu. 6. ed. Porto Alegre: Bookman. 2013.

GÜNTHER, Klaus. Responsabilização na sociedade civil. In: PÜSCHEL, Flavia Portella; MACHADO, Marta Rodriguez de Assis (Orgs.). Teoria da responsabilidade no estado democrático de direito: textos de Klaus Günther. São Paulo: Saraiva, 2009. p. 1-26. (Série Direito em Debate. Direito, Desenvolvimento, Justiça).

HASSEMER, Winfried. Derecho penal simbólico y protección de bienes jurídicos. Traducción de Elena Larrauri. Nuevo Foro Penal, n. 51, p. 17-30, enero 1991. Disponível em: $<$ http://publicaciones.eafit.edu.co/index.php/nuevo-foro-

penal/article/download/4084/3337/0. . . Acesso em: $21 \mathrm{dez} .2017$.

. Direito penal libertário. Coordenação de Luiz Moreira; tradução de Regina Greve. Belo Horizonte: Del Rey, 2007.

HESPANHA, António Manuel: Cultura jurídica europeia: síntese de um milénio. Coimbra: Almedina, 2012.

HIRONAKA, Giselda Maria Fernandes Novaes. Responsabilidade pressuposta. São Paulo: Del Rey, 2005.

. Responsabilidade pressuposta: evolução de fundamentos e de paradigmas da responsabilidade civil na contemporaneidade. Revista da Faculdade de Direito da UFG, Goiânia, GO, v. 31, n. 1, p. 33-59, out. 2010. Disponível em:

$<$ https://www.revistas.ufg.br/revfd/article/view/12029/7983>. Acesso em: 03 abr. 2017.

HOBSBAWM, Eric John. Era dos extremos: o breve século XX: 1914-1991. 2. ed., 35. reimpr. Tradução de Marcos Santarrita. São Paulo: Companhia das Letras, 2007.

HONG, Sungmin et al. Greenland ice evidence of hemispheric lead pollution two millennia ago by greek and roman civilizations. Science, New Series, v. 265, No. 5.180, 1994, p. 1.841-1.843. Disponível em: <www.jstor.org/stable/2884653>. Acesso em: 10 dez. 2017.

HOUAISS, Antônio; VILLAR, Mauro de Salles. Dicionário Houaiss de Língua Portuguesa. Rio de Janeiro: Objetiva, 2001.

HUME, David. Investigação acerca do entendimento humano. Tradução de Anoar Aiex. São Paulo: Nova Cultural, 1999. (Os pensadores).

HUNGRIA, Nélson. Comentários ao Código Penal. 4. ed. Rio de Janeiro: Forense, 1958. v. 1, t. 1 e 2 .

IHERING, Rudolf Von. A luta pelo direito. Tradução de J. Cretella Jr. e Agnes Cretella. 4. ed. São Paulo: Revista dos Tribunais, 2004. 
INSTITUTO BRASILEIRO DE GEOGRAFIA E ESTATÍSTICA (IBGE). Pesquisa nacional de saneamento básico 2008. Rio de Janeiro, 2010. Disponível em:

$<$ https://biblioteca.ibge.gov.br/visualizacao/livros/liv45351.pdf $>$. Acesso em: $17 \mathrm{dez}$. 2017.

JAKOBS, Günther. Danosidade social?: anotações sobre um problema teórico fundamental do direito penal. In: SAAD-DINIZ, Eduardo; POLAINO-ORTS, Miguel (Orgs.). Teoria da pena, bem jurídico e imputação. São Paulo: LiberArs, 2012. p. 93-107.

. Fundamentos do direito penal. Tradução de André Luís Callegari. São Paulo: Revista dos Tribunais, 2003.

. ¿Qué protege el derecho penal: bienes jurídicos o la vigencia de la norma? In: MONTEALEGRE LYNETT, Eduardo (Coord.). El funcionalismo en derecho penal: libro homenaje al professor Günther Jakobs. Bogotá: Universidad Externado de Colombia, 2003. v. 1, p. 39-56.

JIMÉNEZ CARTAGENA, Claudio. Contaminantes orgánicos emergentes en el ambiente: produtos farmaceuticos. Revista Lasallista de Investigación, Antioquia, Colombia, Corporación Universitaria Lasallista, v. 8, n. 2, p. 143-153, jul./dic., 2011. Disponível em: $<$ http://www.redalyc.org/articulo.oa?id=69522607016>. Acesso em: 16 nov. 2017.

JONAS, Hans. O princípio responsabilidade: ensaio de uma ética para a civilização tecnológica. Tradução de Marijane Lisboa e Luiz Barros Montez. Rio de Janeiro: Contraponto; Editora PUC-Rio, 2006.

JOSSERAND, Louis. Evolução da responsabilidade civil. Revista Forense, Rio de Janeiro, v. 38, n. 86, p. 548-559, abr./jun. 1941.

JUSTINIANO I. Digesto de Justiniano, liber primus: introdução ao direito romano. 3 ed. rev. Tradução de Hélcio Maciel França Madeira. São Paulo: Revista dos Tribunais; Osasco: Centro Universitário FIEO - UNIFIEO, 2002.

KELSEN, Hans. Teoria pura do direito. Tradução de João Baptista Machado. 6. ed. São Paulo: Martins Fontes, 1998.

KOURILSKY, Philippe; VINEY, Geneviève. Le principe de précaution. Paris: Odile Jacob, 2000.

KUHN, Thomas S. A estrutura das revoluções científicas. Tradução de Beatriz Vianna Boeira e Nelson Boeira. 10. ed. São Paulo: Perspectiva, 2011.

KÜSTER, Anette; ADLER, Nicole. Pharmaceuticals in the environment: scientific evidence of risks and its regulation. Philosophical Transactions of the Royal Society B: Biological Sciences, v. 369, No. 1.656, p. 1-8, 2014. [Online]. Disponível em: $<$ https://www.ncbi.nlm.nih.gov/pmc/articles/PMC4213597/pdf/rstb20130587.pdf>. Acesso em: 31 jul. 2017. 
LAINGUI, André. La doctrine europeenne du droit penal à l'époque moderne (XVIeXVIIIe siècle). Revue d'Histoire des Facultés de Droit et de la Science Juridique, n. 13, p. 75-89, 1992. Disponível em: <https://univ-droit.fr/docs/recherche/rhfd/pdf/013-1992/131992_p075-089.pdf>. Acesso em: 29 nov. 2017.

LAINGUI, André; LEBIGRE, Arlette. Histoire du droit penal: le droit penal. Paris: Cujas, 1979. v. 1.

LAMBERT-FAIVRE, Yvonne. L'évolution de la responsabilité civile d'une dette de responsabilité a une créance d'indemnisation. Revue Trimestrielle de Droit Civil, Paris, v. 86, n. 1, p. 1-19, janv./mars. 1987. Disponível em: $<$ http://jktd.fr/data/uploads/faitjuridique/seance-1-la-responsabilite-civile-au-xxieme-siecle-r.pdf $>$. Acesso em: 22 out. 2017.

LANFREDI, Geraldo Ferreira (Coord.). Novos rumos do direito ambiental, nas áreas civil e penal. Campinas, SP: Millennium, 2006.

LARENZ, Karl. Metodologia da ciência do direito. 3. ed. Tradução de José Lamego. Lisboa: Fundação Calouste Gulbenkian, 1997.

LASCOUMES, Pierre. La précaution comme anticipation des risques résiduels et hybridation de la responsabilité. L'Année Sociologique, Paris, 3ème. série, v. 46, n. 2, p. 359-382, 1996. Disponível em: <http://www.jstor.org/stable/27889486>. Acesso em: 09 nov. 2017.

. La précaution, un nouveau standard de jugement. Esprit, Paris, n. 237 (11), p. 129-140, nov. 1997. Disponível em <http://www.jstor.org/stable/24277669>. Acesso: 09 nov. 2017.

LEMOS, Patrícia Faga Iglecias. Direito ambiental: responsabilidade civil e proteção ao meio ambiente. 3. ed. rev., atual. e ampl. São Paulo: Revista dos Tribunais, 2010.

. Meio ambiente e responsabilidade civil do proprietário: análise do nexo causal.

2. ed. rev., atual. e ampl. São Paulo: Revista dos Tribunais, 2012.

. Resíduos sólidos e responsabilidade civil pós-consumo. 3. ed. rev. e atual. São Paulo: Revista dos Tribunais, 2014.

. Responsabilidade civil e dano ao meio ambiente: novos rumos. In: MILARÉ, Édis; MACHADO, Paulo Affonso Leme (Orgs.). Direito ambiental: responsabilidade em matéria ambiental. São Paulo: Revista dos Tribunais, 2011. p. 349-364. (Coleção

Doutrinas Essenciais. Direito Ambiental, v. 5).

LEVY, Daniel de Andrade. Responsabilidade civil: de um direito dos danos a um direito das condutas lesivas. São Paulo: Atlas, 2012.

LIMA, Alvino. Culpa e risco. 2. ed. rev. e atual pelo prof. Ovidio Rocha Barros Sandoval. São Paulo: Revista dos Tribunais, 1998. (RT Clássicos). 
LIPOVETSKY, Gilles. O crepúsculo do dever: a ética indolor dos novos tempos democráticos. Tradução de Fátima Gaspar e Carlos Gaspar. Lisboa: Dom Quixote, 1994.

LISZT, Franz von. Tratado de direito penal alemão. Tradução e comentários de José Higino Duarte Pereira; atualização e notas Ricardo Rodrigues Gama. Campinas, SP: Russel, 2003. v. 1.

LOPES, José Reinaldo de Lima. O direito na história: lições introdutórias. São Paulo: Max Limonad, 2000.

LOPES, José Reinaldo de Lima; QUEIROZ, Rafael Mafei Rabelo; ACCA, Thiago dos Santos. Curso de história do direito. 3. ed. Rio de Janeiro: Forense; São Paulo: Método, 2013.

LOPEZ, Teresa Ancona. Principais linhas da responsabilidade civil no direito brasileiro contemporâneo. Revista da Faculdade de Direito da Universidade de São Paulo, São Paulo, v. 101, p. 111-152, jan./dez. 2006. Disponível em:

<http://www.revistas.usp.br/rfdusp/article/view/67701/70309>. Acesso em: 01 nov. 2017. Latin, 2010.

Princípio da precaução e evolução da responsabilidade civil. São Paulo: Quartier Responsabilidade civil na sociedade de risco. Revista da Faculdade de Direito da Universidade de São Paulo, São Paulo, v. 105, p. 1.223-1.234, jan./dez. 2010. Disponível em: <www.periodicos.usp.br/rfdusp/article/download/67932/70540>. Acesso em: 11 fev. 2017.

LOPEZ, Teresa Ancona; LEMOS, Patrícia Faga Iglecias; RODRIGUES JÚNIOR, Otávio Luiz (Coords.). Sociedade de risco e direito privado: desafios normativos, consumeristas e ambientais. São Paulo: Atlas, 2013.

LUHMANN, Niklas. Risk: a sociological theory. Translated by Rhodes Barrett. 4th. printing. New Brunswick, NJ: Transaction Publishers, 2008.

MACHADO, Fábio Guedes de Paula. Crise do direito penal. In: MILARÉ, Édis; MACHADO, Paulo Affonso Leme (Orgs.). Direito ambiental: fundamentos do direito ambiental. São Paulo: Revista dos Tribunais, 2011. p. 173-198. (Coleção Doutrinas Essenciais. Direito Ambiental, v. 1).

MACHADO, Maíra Rocha. A responsabilidade civil é independente da criminal, em termos: a propósito da contribuição da criminologia positivista à transformação da responsabilidade civil. Revista Brasileira de Ciências Criminais, RBCCrim, v. 15, n. 65, p. 317-344, mar./abr. 2007. [Online]. Disponível em:

$<$ https://professorhoffmann.files.wordpress.com/2012/07/encontro-02-artigo.pdf $>$. Acesso em: 18 mar. 2017.

MACHADO, Paulo Affonso Leme. Direito ambiental brasileiro. 25. ed. rev., ampl. e atual. São Paulo: Malheiros, 2017. 
. Da poluição e de outros crimes ambientais na Lei 9.605/1998. In: MILARÉ, Édis; MACHADO, Paulo Affonso Leme (Orgs.). Direito ambiental: conservação e degradação do meio ambiental. São Paulo: Revista dos Tribunais, 2011. p. 969-984. (Coleção Doutrinas Essenciais. Direito Ambiental, v. 2).

. O princípio da precaução e a avaliação de riscos. Lusíada. Direito e Ambiente, n. 1, p. 275-295, 2008. Disponível em:

$<$ http://revistas.lis.ulusiada.pt/index.php/lda/article/view/2120/2239>. Acesso em: 26 nov. 2017.

. Recursos hídricos: direito brasileiro e internacional. São Paulo: Malheiros, 2002.

MANSO PORTO, Teresa. La consumación en los delitos contra el medio ambiente: comparación de los modelos colombiano, español y alemán. In: MONTEALEGRE LYNETT, Eduardo (Coord.). El funcionalismo en derecho penal: libro homenaje al professor Günther Jakobs. Bogotá: Universidad Externado de Colombia, 2003, v. 1, p. 445-461.

MARAVER GÓMEZ, Mario. Riesgo permitido por legitimación histórica. In: MONTEALEGRE LYNETT, Eduardo (Coord.). El funcionalismo en derecho penal: libro homenaje al professor Günther Jakobs. Bogotá: Universidad Externado de Colombia, 2003. v. 2, p. 207-235.

MARCHI, Eduardo C. Silveira. A propriedade horizontal no direito romano. 2. ed., 2. tiragem. São Paulo: Quartier Latin. 2003.

MARQUES, Oswaldo Henrique Duek. Fundamentos da pena. 3. ed. São Paulo: WMF Martins Fontes, 2016. (Biblioteca Jurídica WMF).

MARTIN, Gilles. Direito do ambiente e danos ecológicos. Revista Crítica de Ciências Sociais, Coimbra, n. 31, p. 115-142, mar. 1991. Disponível em:

$<$ http://www.ces.uc.pt/publicacoes/rccs/artigos/31/Gilles\%20Martin\%20-

$\% 20$ Direito $\% 20$ do $\% 20$ Ambiente $\% 20 \mathrm{e} \% 20$ Danos $\% 20$ Ecologicos.pdf $>$. Acesso em: 28 maio 2017.

. Précaution et évolution du droit. In: GODARD, Olivier (Dir.). Le principe de précaution: dans la conduite des affaires humaines. Paris: Maison des Sciences de l'Homme; Institut national de la recherche agronomique (INRA), 1997. p. 331-351.

MARTINS, Veridiana T. de S; BABINSKI, Marly. Geocronologia: o tempo registrado nas rochas. Instituto de Geociências da USP. Disponível em:

$<$ http://www.igc.usp.br/index.php?id=304>. Acesso em: 25 jan.2017.

MARTINS JUNIOR, Wallace Paiva. Despoluição das águas. In: MILARÉ, Édis; MACHADO, Paulo Affonso Leme (Orgs.). Direito ambiental: conservação e degradação do meio ambiental. São Paulo: Revista dos Tribunais, 2011. p. 1.053-1.076. (Coleção Doutrinas Essenciais. Direito Ambiental, v. 2). 
MAXIMILIANO, Carlos. Hermenêutica e aplicação do direito. 15. ed. Rio de Janeiro: Forense, 1995.

MAZEAUD, Henri; MAZEAUD, Léon. Traité théorique et pratique de la responsabilité civile délictuelle et contractuelle. 4. ed. Paris: Recueil Sirey, 1947. v. 1.

MELLO-DA-SILVA, Carlos Augusto; FRUCHTENGARTEN, Ligia. Riscos químicos ambientais à saúde da criança. Jornal de Pediatria, (Rio J.), Porto Alegre, v. 81, n. 5, supl. p. s205-s211, nov. 2005. Disponível em:

$<\mathrm{http}: / /$ www.scielo.br/scielo.php?script=sci_arttext\&pid=S0021-

$75572005000700011 \& \operatorname{lng}=$ en\&nrm=iso\&tlng=pt $>$. Acesso em: 12 jul. 2017.

MESSUTI, Ana. O tempo como pena. Tradução de Tadeu Antonio Dix Silva e Maria Clara Veronesi de Toledo. São Paulo: Revista dos Tribunais, 2003.

MILARÉ, Édis. Direito do ambiente: gestão ambiental em foco: doutrina, jurisprudência, glossário. 6. ed. rev., atual. e ampl. São Paulo: Revista dos Tribunais, 2009.

MILARÉ, Édis; COIMBRA, José de Ávila Aguiar. Antropocentrismo x ecocentrismo na ciência jurídica. Revista de Direito Ambiental, São Paulo, Revista dos Tribunais, v. 9, n. 36, p. 9-41, out./dez. 2004.

MILARÉ, Édis; MACHADO, Paulo Affonso Leme (Orgs.). Direito ambiental: responsabilidade em matéria ambiental. São Paulo: Revista dos Tribunais, 2011. (Coleção Doutrinas Essenciais. Direito Ambiental, v. 5).

MIR PUIG, Santiago. Introducción a las bases del derecho penal: concepto y método. 2. ed., 2. reimpr. Montevideo; Buenos Aires: Editorial B de F, 2007. (Colección Maestros del Derecho Penal, n. 5).

MONTEALEGRE LYNETT, Eduardo (Coord.). El funcionalismo en derecho penal: libro homenaje al professor Günther Jakobs. Bogotá: Universidad Externado de Colombia, 2003. v. 1-2.

MONTEIRO, Washington de Barros. Da interpretação das leis. Revista da Faculdade de Direito da Universidade de São Paulo, São Paulo, v. 57, p. 141-151, jan. 1962. Disponível em: <http://www.revistas.usp.br/rfdusp/article/view/66399/69009>. Acesso em: $01 \mathrm{dez}$. 2017.

MOORE, Michael S. Causalidad y responsabilidade: un ensayo sobre derecho, moral y metafísica. Traducción de Tobías J. Schleider. Madrid: Marcial Pons, 2011.

MORAES, Maria Celina Bodin de. A constitucionalização do direito civil e seus efeitos sobre a responsabilidade civil. Direito, Estado e Sociedade, v. 9, n. 29. p. 233-258, jul/dez 2006. Disponível em:

$<$ http://egov.ufsc.br/portal/sites/default/files/a_constitucionalizacao_do_direito_civil_e_se us.pdf $>$. Acesso em: 02 out. 2017. 
MORATO, Antonio Carlos. Codificação e descodificação: uma análise acerca do tema. Revista da Faculdade de Direito da Universidade de São Paulo, São Paulo, v. 98, p. 95120, jan. 2003. Disponível em: <http://www.revistas.usp.br/rfdusp/article/view/67581>. Acesso em: 11 out. 2017.

MORILLAS CUEVA, Lorenzo. Las diversas variables de la protección del agua en el ámbito punitivo. In: PERIS RIERA, Jaime Miguel (Dir.); CUESTA PASTOR, Pablo (Coord.) La tutela penal del agua. Madrid: Dykinson, 2009. p. 37-83.

MORSELLO, Marco Fabio. A responsabilidade civil e a socialização dos riscos: o sistema neozolandês e a experiência escandinava. Revista da Escola de Magistratura, São Paulo, ano 7, n. 2, p. 13-22, jul./dez. 2006. Disponível em:

$<$ https://api.tjsp.jus.br/Handlers/Handler/FileFetch.ashx?codigo=20522>. Acesso em: 05 abr. 2017.

MÜLLER-TUCKFELD, Jens Christian. Ensayo para la abolición del derecho penal del medio ambiente. In: INSTITUTO DE CIENCIAS CRIMINALES DE FRANKFURT (Ed.). Área de Derecho Penal de la Universidad Pompeu Fabra (Ed. española). La insostenible situación del derecho penal. Granada: Comares, 2000. p. 507-530. Disponível em: <http://cubc.mx/biblioteca/libros/ICCF\%20-

$\% 20 \mathrm{La} \% 20$ Insostenible\%20Situaci\%C3\%B3n\%20del\%20Derecho\%20Penal.pdf $>$. Acesso em: 04 mar. 2017.

NAZO, Georgette N.; MUKAI, Toshio. O direito ambiental no Brasil: evolução histórica e a relevância do direito internacional do meio ambiente. Revista de Direito Administrativo, Rio de Janeiro, v. 223, p. 75-104, jan. 2001. Disponível em:

$<$ http://bibliotecadigital.fgv.br/ojs/index.php/rda/article/view/48313>. Acesso em: 10 dez. 2017.

NAVARRETE, Miguel Polaino. Para onde sopram os ventos do direito penal? In: SAADDINIZ, Eduardo; POLAINO-ORTS, Miguel (Orgs.). Teoria da pena, bem jurídico e imputação. São Paulo: LiberArs, 2012. p. 77-90.

NERY JUNIOR, Nelson. Autonomia do direito ambiental. In: D'ISEP, Clarissa Ferreira Macedo; NERY JÚNIOR. Nelson; MEDAUAR, Odete (Coords.). Políticas públicas ambientais: estudos em homenagem ao professor Michel Prieur. São Paulo: Revista dos Tribunais, 2009. p. 194-218.

NERY JUNIOR, Nelson; NERY, Rosa Maria B. B. de Andrade. Responsabilidade civil, meio-ambiente e ação coletiva. In: BENJAMIN, Antônio Herman Vasconcelos e (Coord.). Dano ambiental: prevenção, reparação e repressão. São Paulo: Revista dos Tribunais, 1993. p. 278-307. (Biblioteca de Direito Ambiental, v. 2).

NORONHA, Edgard Magalhães. Direito penal: introdução e parte geral. 26. ed. atualizada por Adalberto José Q. T. de Camargo Aranha nos termos da Lei n. 7.209/84. São Paulo:

Saraiva, 1989. v. 1.

NORONHA, Fernando. Desenvolvimentos contemporâneos da responsabilidade civil. Sequência: Estudos Jurídicos e Políticos, Florianópolis, SC, UFSC, v. 19, n. 37, p. 21-37, jan. 1998. Disponível em:

$<$ https://periodicos.ufsc.br/index.php/sequencia/article/view/15533/14089>. Acesso em: 22 nov. 2017. 
NOSTRE, Guilherme Alfredo de Moraes. Direito penal das águas. Tese (Doutorado) Faculdade de Direito da Universidade de São Paulo, São Paulo, 2007.

NUNES, Antônio de Pádua. A reforma dos códigos - o direito das águas no anteprojeto do código civil. In: MILARÉ, Édis; MACHADO, Paulo Affonso Leme (Orgs.). Direito ambiental: conservação e degradação do meio ambiental. São Paulo: Revista dos Tribunais, 2011. p. 1.079-1.084. (Coleção Doutrinas Essenciais. Direito Ambiental, v. 2).

NUSDEO, Ana Maria de Oliveira. Desenvolvimento e ecologia revisitado: evolução do debate e perspectivas atuais. In: NUSDEO, Fábio (Coord.). O direito econômico na atualidade. São Paulo: Revista dos Tribunais, 2015. v. 1, p. 227-250.

ONU: população mundial é de 7,2 bilhões de pessoas. Estadão, Internacional, São Paulo, 13 de junho de 2013. Disponível em:

$<$ http://internacional.estadao.com.br/noticias/geral,onu-populacao-mundial-e-de-7-2bilhoes-de-pessoas,1042156>. Acesso em: 21 maio 2017.

A ONU e a água. Disponível em: $<$ https://nacoesunidas.org/acao/agua/ $>$. Acesso em: 10 dez. 2017.

ORDEIG, Enrique Gimbernat. Conceito e método da ciência do direito penal. Tradução de José Carlos Gobbis Pagliuca; revisão da tradução de Luiz Flávio Gomes. São Paulo: Revista dos Tribunais, 2002. (Série As Ciências Criminais no século XXI, v. 9).

ORGANIZAÇÃO DAS NAÇÕES UNIDAS SOBRE MEIO AMBIENTE E DESENVOLVIMENTO. Declaração do Rio sobre Meio Ambiente e Desenvolvimento. Rio de Janeiro, 3 a 14 de junho de 1992. Disponível em:

$<$ http://www.onu.org.br/rio20/img/2012/01/rio92.pdf>. Acesso em: 15 dez. 2017.

ORSI, Carlos. Água de 20 capitais tem 'contaminantes emergentes'. Jornal da Unicamp, Campinas, de 23 de setembro de 2013 a 29 de setembro de 2013, ANO 2013, p. 3, n. 576. Disponível em:

$<$ http://www.unicamp.br/unicamp/sites/default/files/jornal/paginas/ju_576_pagina_03_we b.pdf $>$. Acesso em: $10 \mathrm{dez} .2017$.

OST, François. A natureza à margem da lei: a ecologia à prova do direito. Tradução de Joana Chaves. Lisboa: Instituto Piaget, 1995.

Piaget, 1999.

O tempo do direito. Tradução de Maria Fernanda Oliveira. Lisboa: Instituto

PALANIAPPAN, Meena et al. Clearing the waters: a focus on water quality solutions. Nairobi, Kenya: United Nations Environment Programme (UNEP), 2010. Disponível em: $<\mathrm{http}$ ://pacinst.org/wp-content/uploads/2013/02/clearing_the_waters3.pdf $>$. Acesso em: 09 out. 2017.

PEREIRA, Caio Mário da Silva. Instituições de direito civil: direitos reais. 25. ed. rev. e atual. por Carlos Edison do Rêgo Monteiro Filho. Rio de Janeiro: Forense, 2017. v. 4. 
PEREIRA, Francisco de Assis. Os fundamentos da indução e a teoria empírica da causalidade em John Stuart Mill. Revista Portuguesa de Filosofia, Braga, PT, v. 34, n. 2/3, p. 183-220, 1978. Disponível em: <https://www.jstor.org/stable/40335525>. Acesso em: 01 dez. 2017.

PERIS RIERA, Jaime Miguel. Tutela penal del agua. In: PERIS RIERA, Jaime Miguel (Dir.); CUESTA PASTOR, Pablo (Coord.). La tutela penal del agua. Madrid: Dykinson, 2009. p. 21-36.

PLANAS, Ricardo Robles. Estudos de dogmática jurídico-penal: fundamentos, teoria do delito e direito penal econômico. Belo Horizonte: D’Plácido, 2016. (Coleção Ciência Criminal Contemporânea, v. 6).

PORCHAT, Reynaldo. Direito romano: (Para uso dos alumnos do $1^{\circ}$ anno do curso jurídico): parte I, generalidades. Revista da Faculdade de Direito, São Paulo, v. 12, p. 209-218, jan. 1904. Disponível em:

$<$ https://www.revistas.usp.br/rfdsp/article/view/65036/67648>. Acesso em: 05 out. 2017.

POVEDA VELASCO, Ignácio Maria. Direito, jurisprudência e justiça no pensamento clássico (greco-romano). Revista da Faculdade de Direito da Universidade de São Paulo, São Paulo, v. 101, p. 21-32, jan./dez. 2006. Disponível em:

$<$ http://www.revistas.usp.br/rfdusp/article/view/67697/70305>. Acesso em: 02 dez. 2017.

POZUELO PÉREZ, Laura. De nuevo sobre la denominada “expansión” del derecho penal: una relectura de los planteamientos críticos. In: MONTEALEGRE LYNETT, Eduardo (Coord.). El funcionalismo en derecho penal: libro homenaje al professor Günther Jakobs. Bogotá: Universidad Externado de Colombia, 2003. v. 2, p. 107-133.

PRADO, Alessandra Rapassi Mascarenhas. Crime de poluição: uma resposta do direito penal aos novos riscos. Curitiba: Juruá, 2010.

PRIEUR, Michel. Droit de l'environnement. 4e éd. Paris: Dalloz, 2001.

. Le principe de précaution. Disponível em $<$ http://www.legiscompare.fr/siteweb/IMG/pdf/2-Prieur.pdf $>$. Acesso em: 17 out. 2017.

PROGRAMA DE ANÁLISE DE RESÍDUOS DE AGROTÓXICOS EM ALIMENTOS (PARA). Relatório de atividades de 2013 a 2015. Brasília: Agência Nacional de Vigilância Sanitária (Anvisa), 2016. Disponível em: $<$ http://portal.anvisa.gov.br/documents/111215/0/Relatório+PARA+20132015_VERSÃO-FINAL.pdf/494cd7c5-5408-4e6a-b0e5-5098cbf759f8> Acesso em: 10 dez. 2017.

PUCCI, Rafael Diniz. Responsabilidade e direito penal: discussão jurídico-sociológica. Revista da Faculdade de Direito da Universidade de São Paulo, São Paulo, v. 104, p. 683-721, jan./dez. 2009. Disponível em:

$<$ https://www.revistas.usp.br/rfdusp/article/download/67875/70483>. Acesso em: 01 nov. 2017. 
QUEIROZ FILHO, Antônio de. Relações entre o direito penal e o civil. Justitia, São Paulo, v. 11, n. 20, p. 55-58, jan./mar. 1958. Disponível em:

$<$ http://www.revistajustitia.com.br/revistas/20cwy8.pdf $>$. Acesso em: 15 ago. 2017.

RAMOS VÁZQUEZ, José Antonio. Del otro lado del espejo: reflexiones desordenadas acerca del derecho penal en la sociedad actual. In: FARALDO CABANA, Patricia (Dir.); BRANDARIZ GARCÍA, José Ángel; PUENTE ABA, Luz María (Coords.). Nuevos retos del derecho penal en la era de la globalización. Valencia: Tirant lo Blanch, 2004. p. 65122.

REALE, Miguel. Filosofia do direito. 20. ed. São Paulo: Saraiva, 2007.

. Lições preliminares de direito. 27. ed. São Paulo: Saraiva, 2002.

REALE JÚNIOR, Miguel. Meio ambiente e direito penal brasileiro. In: MILARÉ, Édis; MACHADO, Paulo Affonso Leme (Orgs.). Direito ambiental: fundamentos do direito ambiental. São Paulo: Revista dos Tribunais, 2011. p. 291-309. (Coleção Doutrinas Essenciais. Direito Ambiental, v. 1).

REBOUÇAS, Aldo da Cunha. Proteção dos recursos hídricos. In: MILARÉ, Édis; MACHADO, Paulo Affonso Leme (Orgs.). Direito ambiental: conservação e degradação do meio ambiental. São Paulo: Revista dos Tribunais, 2011. p. 25-64. (Coleção Doutrinas Essenciais. Direito Ambiental, v. 2).

REINIG, Guilherme Henrique Lima. O problema da causalidade na responsabilidade civil: a teoria do escopo da proteção da norma (Scutzzwecktheorie) e sua aplicabilidade no direito civil brasileiro. Tese (Doutorado) - Faculdade de Direito da Universidade de São Paulo, São Paulo, 2015.

REYNOL, Fabio. Contaminantes emergentes na água. Agência FAPESP, São Paulo, de 30 setembro de 2010. Disponível em:

$<$ http://agencia.fapesp.br/contaminantes_emergentes_na_agua/12846/>. Acesso em: 10 dez. 2017.

RICHARDSON, Susan D.; TERNES, Thomas A. Water analysis: emerging contaminants and current issues. Analytical Chemistry, v. 86, No. 6, p. 2.813-2.848, 2014. Disponível em: <http://pubs.acs.org/doi/pdf/10.1021/ac500508t>. Acesso em: 10 dez. 2017.

RICOEUR, Paul. O justo ou a essência da justiça. Tradução de Vasco Casimiro. Lisboa: Instituto Piaget, 1997.

RODRÍGUEZ FERRÁNDEZ, Samuel. El agua: ¿Bien jurídico-penal protegido? In: PERIS RIERA, Jaime Miguel (Dir.); CUESTA PASTOR, Pablo (Coord.). La tutela penal del agua. Madrid: Dykinson, 2009. p. 85-120.

ROMEO CASABONA, Carlos María. El principio de precaución en las actividades de riesgo. In: CASTELLANO RAUSELL, Pedro (Dir.). La responsabilidad penal de las actividades de riesgo. Madrid: Consejo General del Poder Judicial, Centro de Documentación Judicial, 2002. P. 13-60. (Cuadernos de Derecho Judicial, n. 3). Disponível em: < http://ppje.poderjudicialchiapas.gob.mx/pdfs/2002-8.pdf >. Acesso em: 30 out. 2017. 
ROSSI, Marina. O 'alarmante' uso de agrotóxicos no Brasil atinge 70\% dos alimentos. El País, abril 2015. Disponível em:

$<$ https://brasil.elpais.com/brasil/2015/04/29/politica/1430321822_851653.html>. Acesso em: 10 dez. 2017.

ROXIN, Claus. Estudos de direito penal. 2. ed. rev. Tradução de Luís Greco. Rio de Janeiro: Renovar, 2008.

. Teoría del tipo penal: tipos abiertos y elementos del deber jurídico. Traducción de Enrique Bacigalupo. Buenos Aires: Depalma, 1979. Disponível em:

$<\mathrm{http}$ ://www.derechopenalenlared.com/libros/claus_roxin_Teoria_del_tipo_penal.pdf $>$. Acesso em: 01 nov. 2017.

RUDÁ, Antonio Sólon. Breve história do direito penal e da criminologia: do primitivismo criminal à era das escolas penais. Rio de Janeiro: Lumen Juris, 2013.

RUSSELL, Bertrand. História da filosofia ocidental: livro 1: a filosofia antiga. Tradução Hugo de Langone. 2. ed. Rio de Janeiro: Nova Fronteira, 2015.

RUFINO, Gilberto D’Ávila. Aspectos jurídicos da poluição: a questão da poluição das águas. In: MILARÉ, Édis; MACHADO, Paulo Affonso Leme (Orgs.). Direito ambiental: conservação e degradação do meio ambiental. São Paulo: Revista dos Tribunais, 2011. p. 775-788. (Coleção Doutrinas Essenciais. Direito Ambiental, v. 2).

SAAD-DINIZ, Eduardo; POLAINO-ORTS, Miguel (Orgs.). Teoria da pena, bem jurídico e imputação. São Paulo: LiberArs, 2012.

SALVADOR CODERCH, Pablo; CASTIÑEIRA PALOU, María Teresa. Prevenir y castigar: liberdad de información y expresión, tutela del honor y funciones del derecho de daños. Madrid: Marcial Pons, 1997.

SALVADOR CODERCH, Pablo; FERNÁNDEZ CRENDE, Antonio. Causalidad y responsabilidad. 3. ed. InDRET, Revista para el Análises del Derecho, Barcelona, n. 1, enero 2006. Disponível em: <http://www.indret.com/pdf/329_es.pdf>. Acesso em: 21 jul. 2017.

SALVADOR CODERCH, Pablo; GAROUPA, Nuno; GÓMEZ LINGÜERRE, Carlos. El circulo de responsables: la evanescente distinción entre la responsabilidade per culpa y objetiva. Traducción de Carlos Gómez Ligüerre. InDRET, Revista para el Análises del Derecho, Barcelona, n. 4, oct. 2005. Disponível em:

$<$ http://www.indret.com/pdf/309_es.pdf $>$. Acesso em: 09 out. 2017.

SALVADOR NETTO, Alamiro Velludo. Finalidades da pena: conceito material de delito e sistema penal integral. São Paulo: Quartier Latin, 2009.

SANTOS, Boaventura de Sousa. Introdução a uma ciência pós-moderna. Rio de Janeiro: Graal, 1989. 
SAUVÉ, Sébastien; DESROSIERS, Mélanie. A review of what is an emerging contaminant. Chemistry Central Journal, v. 8, No. 1, 2014. Disponível em: $<$ https://www.ncbi.nlm.nih.gov/pmc/articles/PMC3938815/pdf/1752-153X-8-15.pdf $>$. Acesso em: 10 dez. 2017.

SAVIGNY, Friedrich Carl von. De la vocación de nuestra época para la legislación y la ciencia del derecho. Traducción de José Díaz García. Madrid: Universidad Carlos III de Madrid, 2015. Disponível em: <http://hdl.handle.net/10016/21520>. Acesso em: 27 abr. 2017.

. Metodologia jurídica. Tradução de Heloisa Buratti. São Paulo: Rideel, 2005 (Biblioteca Clássica).

SCHREIBER, Anderson. Novos paradigmas da responsabilidade civil: da erosão dos filtros da reparação à diluição dos danos. 6. ed. São Paulo: Atlas, 2015.

SCHULZ, Lorenz. De la aceleración de las condiciones de vida: reflexiones sobre la reacción adecuada del derecho penal. In: INSTITUTO DE CIENCIAS CRIMINALES DE FRANKFURT (Ed.). Área de Derecho Penal de la Universidad Pompeu Fabra (Ed. española). La insostenible situación del derecho penal. Granada: Comares, 2000. p. 445468. Disponível em: <http://cubc.mx/biblioteca/libros/ICCF\%20$\% 20 \mathrm{La} \% 20$ Insostenible\%20Situaci\%C3\%B3n\%20del\%20Derecho\%20Penal.pdf $>$. Acesso em: 21 nov. 2017.

SCHÜNEMANN, Bernd. O direito penal é a última ratio da proteção de bens jurídicos!: sobre os limites invioláveis ao direito penal em um estado de direito liberal. Tradução de Luís Greco. Revista Brasileira de Ciências Criminais, RBCCrim, v. 13, n. 53, p. 9-37, mar./ abr. 2005.

Tecnos, 2002.

Temas actuales y permanentes del derecho penal después del milenio. Madrid:

SÊNECA. Sobre a brevidade da vida. Sobre a firmeza do sábio. Diálogos. Tradução de José Eduardo S. Lohner. São Paulo: Penguin Classics Companhia das Letras, 2017.

SHECAIRA, Sérgio Salomão; CORRÊA JUNIOR, Alceu. Teoria da pena: finalidades, direito positivo, jurisprudência e outros assuntos de ciência criminal. São Paulo: Revista dos Tribunais, 2002.

SILVA, Ana Lúcia. Interferentes endócrinos no meio ambiente: um estudo de caso em amostras de água in natura e efluente de estação de tratamento de esgotos da região metropolitana de São Paulo. Tese (Doutorado) - Faculdade de Saúde Pública, Universidade de São Paulo, São Paulo, 2009. Disponível em: $<$ http://www.teses.usp.br/teses/disponiveis/6/6134/tde-21072009-091520/>. Acesso em: 12 jul. 2017.

SILVA, Patrícia Bressan da. Aspectos semiológicos do direito do ambiente. Belo Horizonte: Del Rey, 2004. 
SILVA, Tadeu A. Dix. Globalização e direito penal brasileiro: acomodação ou indiferença? Revista Brasileira de Ciências Criminais, RBCCrim, v. 6, n. 23, p. 81-96, jul./set., 1998.

SILVA, Wilson Melo da. Responsabilidade sem culpa e socialização do risco. Belo Horizonte: Bernardo Álvares, 1962.

SILVA SÁNCHEZ, Jesús-María. Carta a um estudiante de derecho penal. In: SILVEIRA, Renato de Mello Jorge; SALVADOR NETTO, Alamiro Velludo; SOUZA, Luciano Anderson de (Coords.). Direito penal na pós-modernidade: escritos em homenagem a Antonio Luis Chaves de Camargo. São Paulo: Quartier Latin, 2015. p. 265-284.

. A expansão do direito penal: aspectos da política criminal nas sociedades pósindustriais. Tradução da 2. edição espanhola de Luiz Otavio de Oliveira Rocha ; revisão de Luiz Flávio Gomes. São Paulo: Revista dos Tribunais, 2002.

. Eficiencia y derecho penal. Anuario de Derecho Penal y Ciencias Penales, v. 49, fasc. 1, p. 93-127, enero/abr. 1996. Disponível em:

$<$ http://www.cienciaspenales.net/files/2016/11/1996_fasc_I.pdf $>$. Acesso em: 13 ago. 2017.

SILVA SÁNCHEZ, Jesús-María; MONTANER FERNÁNDEZ, Raquel. Los delitos contra el medio ambiente: reforma legal y aplicación judicial. Barcelona: Atelier, 2012.

SILVA-SÁNCHEZ, Solange S. Política de meio ambiente no Brasil: a construção da cidadania ambiental. Plural, São Paulo, v. 6, p. 20-46, 1999. Disponível em:

$<\mathrm{http}: / / w w w . r e v i s t a s . u s p . b r / p l u r a l / a r t i c l e / v i e w / 77122 / 81001>$. Acesso em: 10 dez. 2017.

SILVEIRA, Evanildo da. Contaminação emergente: presença de cafeína em água tratada é indício da presença de outras substâncias nocivas. Pesquisa Fapesp, São Paulo, p. 70-71, edição 230, abr. 2015. Disponível em: <http://revistapesquisa.fapesp.br/wpcontent/uploads/2015/04/070-071_Cafeina_230.pdf>. Acesso em: 10 dez. 2017.

SILVEIRA, Renato de Mello Jorge. Bem jurídico-penal. Leituras conflituosas. In: SAADDINIZ, Eduardo; POLAINO-ORTS, Miguel (Orgs.). Teoria da pena, bem jurídico e imputação. São Paulo: LiberArs, 2012. p. 129-147.

. Direito penal econômico como direito penal de perigo. São Paulo: Revista dos Tribunais, 2006.

. Direito penal supra-individual: interesses difusos. São Paulo: Revista dos Tribunais, 2003. (Ciência do Direito Penal Contemporânea, v. 3).

SOARES, Guido Fernando Silva. O meio ambiente e a justiça no mundo globalizado. In: PENTEADO, Jaques de Camargo, (Coord.). 10 anos da Constituição e a justiça penal, meio ambiente, drogas, globalização, o caso Pataxó. São Paulo: Revista dos Tribunais, 1999. p. 65-118. (Justiça Penal: Críticas e Sugestões, 6). 
SÓFOCLES. Antígona. Tradução de J. B. de Mello Souza. Fonte digital. Clássicos Jackson, v. XXII. 2005. Disponível em:

$<$ http://direitorio.fgv.br/sites/direitorio.fgv.br/files/antigona.pdf $>$. Acesso em: 15 set. 2017.

SOUZA, Luciano Anderson de. Expansão do direito penal e globalização. São Paulo: Quartier Latin, 2007.

STEIGLEDER, Annelise Monteiro. Considerações sobre o nexo de causalidade na responsabilidade civil por dano ao meio ambiente. In: MILARÉ, Édis; MACHADO, Paulo Affonso Leme (Orgs.). Direito ambiental: responsabilidade em matéria ambiental. São Paulo: Revista dos Tribunais, 2011. p. 43-66. (Coleção Doutrinas Essenciais. Direito Ambiental, v. 5).

STOCO, Rui. Tratado de responsabilidade civil: doutrina e jurisprudência. 10. ed. rev., atual. e reform., com acréscimo de acórdãos do STF e STJ. São Paulo: Revista dos Tribunais, 2014.

STRECK, Lenio Luiz. Hermenêutica jurídica e $(m)$ crise: uma exploração hermenêutica da construção do direito. 11. ed. rev., atual. e ampl. Porto Alegre: Livraria do Advogado, 2014.

SUSTEIN, Cass R. Para além do princípio da precaução. Revista de Direito Administrativo, Rio de Janeiro, v. 259, p. 11-71, jan./abr. 2012. Disponível em: $<$ http://bibliotecadigital.fgv.br/ojs/index.php/rda/article/view/8629/7373>. Acesso em: 09 nov. 2017.

TAVARES, Juarez. Teoria do injusto penal. 3. ed. rev. e ampl. Belo Horizonte: Del Rey, 2003.

TEPEDINO, Gustavo. Notas sobre o nexo de causalidade. Revista Jurídica, São Paulo, v. 50, n. 296, p. 7-18, jun. 2002. Disponível em:

$<$ http://www.prto.mpf.mp.br/pub/biblioteca/NotasNexoCausalidade.pdf $>$. Acesso em: 01 set. 2017.

TERNES, T. A et al. Behavior and occurrence of estrogens in municipal sewage treatment plants. I. Investigations in Germany, Canada and Brazil. Science of the Total Environment, v. 225, No. 1-2, p. 81-90, Jan. 1999. Disponível em:

$<$ http://www.sciencedirect.com/science/article/pii/S0048969798003349>. Acesso em: 25 ago. 2017.

THIBIERGE, Catherine. Libres propos sur l'évolution du droit de la responsabilité (vers um élargissement de la fonction de la responsabilité civile?). Revue Trimestrielle de Droit Civil, Paris, n. 3, p. 561-584, juil./sept. 1999. Disponível em:

$<$ http://jktd.fr/data/uploads/fait-juridique/seance-1-la-responsabilite-civile-au-xxiemesiecle-r.pdf>. Acesso em: 22 out. 2017.

TOLEDO, Francisco de Assis. Princípios básicos de direito penal. 5 ed. São Paulo: Saraiva, 1994. 
TRANSFORMANDO nosso mundo: a Agenda 2030 para o Desenvolvimento Sustentável. Disponível em: <https://nacoesunidas.org/wp-content/uploads/2015/10/agenda2030-ptbr.pdf>. Acesso em: $10 \mathrm{dez} .2017$.

TURESSI, Flávio Eduardo. Bens jurídicos coletivos: proteção penal, fundamentos e limites constitucionais à luz dos mandados de criminalização. Curitiba: Juruá, 2015.

UNITED NATIONS EDUCATIONAL, SCIENTIFIC AND CULTURAL ORGANIZATION (UNESCO); WORLD METEOROLOGICAL ORGANIZATION (WMO). International glossary of hydrology. Geneva: WMO, 2012. (WMO-No. 385). Disponível em: < http://unesdoc.unesco.org/images/0022/002218/221862M.pdf $>$. Acesso em: 10 dez. 2017.

UNITED NATIONS WORLD WATER ASSESSMENT PROGRAMME (WWAP). Relatório Mundial das Nações Unidas sobre o Desenvolvimento dos Recursos Hídricos 2017: resumo executivo: águas residuais: o recurso inexplorado. Disponível em: $<$ http://unesdoc.unesco.org/images/0024/002475/247552por.pdf $>$. Acesso em: $10 \mathrm{dez}$. 2017.

UNITED NATIONS WORLD WATER ASSESSMENT PROGRAMME (WWAP). The United Nations World Water Development Report 3: water in a changing world. Paris: UNESCO; London: Earthscan, 2009. Disponível em:

$<$ http://unesdoc.unesco.org/images/0018/001819/181993e.pdf >. Acesso em: 10 dez. 2017.

UNITED NATIONS WORLD WATER ASSESSMENT PROGRAMME (WWAP). The United Nations World Water Development Report 4: managing water under uncertainty and risk. v. 1. Paris: UNESCO, 2012. Disponível em:

$<$ http://unesdoc.unesco.org/images/0021/002156/215644e.pdf >. Acesso em: 10 dez. 2017.

UNITED NATIONS WORLD WATER ASSESSMENT PROGRAMME (WWAP). The United Nations World Water Development Report 2015: water for a sustainable world. Paris: UNESCO, 2015. Disponível em:

<http://unesdoc.unesco.org/images/0023/002318/231823E.pdf>. Acesso em 10 dez. 2017.

UNITED NATIONS WORLD WATER ASSESSMENT PROGRAMME (WWAP).

Water for people, water for life: a joint report by the twenty three UN agencies concerned with freshwater. New York: UNESCO; Berghahn Books, 2003. Disponível em:

$<$ http://unesdoc.unesco.org/images/0012/001297/129726e.pdf >. Acesso em: 10 dez. 2017.

UNITED STATES ENVIRONMENTAL PROTECTION AGENCY (EPA). Drinking water health advisory for perfluorooctanoic acid (PFOA). EPA Document Number: 822R-16-005 - May 2016. Disponível em: <https://www.epa.gov/sites/production/files/201605/documents/pfoa_health_advisory_final-plain.pdf $>$. Acesso em: 09 out. 2017.

VEIGA, José Eli da. Desenvolvimento sustentável: o desafio do século XXI. Rio de Janeiro: Garamond, 2010.

VILLEY, Michel. Esboço histórico sobre o termo responsável (1977). Tradução de André Rodrigues Corrêa. Revista Direito GV, São Paulo, v. 1, n. 1, p. 135-148, maio 2005. Disponível em:

$<$ bibliotecadigital.fgv.br/ojs/index.php/revdireitogv/article/download/35269/34063>. Acesso em: 10 mar. 2017. 
VINEY, Geneviève. Introduction à la responsabilité. 3e éd. Paris: LGDJ, 2008. (Traité de Droit Civil - Direction de Jacques Ghestin, v. 8).

VINEY, Geneviève; JOURDAIN, Patrice. Les effets de la responsabilité. 2e éd. Paris: LGDJ, 2001. (Traité de Droit Civil - Direction de Jacques Ghestin, v. 6).

WAINER, Ann Helen. Legislação ambiental brasileira: evolução histórica do direito ambiental. In: MILARÉ, Édis; MACHADO, Paulo Affonso Leme (Orgs.). Direito ambiental: fundamentos do direito ambiental. São Paulo: Revista dos Tribunais, 2011. p. 705-721. (Coleção Doutrinas Essenciais. Direito Ambiental, v. 1).

WEISS, Madeline C. et al. The physiology and habitat of the last universal common ancestor. Nature Microbiology, v. 1, No. 9, article number 16116, July 2016. Disponível em: <https://www.nature.com/articles/nmicrobiol2016116>. Acesso em: 10 dez. 2017.

WELZEL, Hans. O novo sistema jurídico-penal: uma introdução à doutrina da ação finalista. 4. ed. rev., atual. e ampl. Tradução de Luiz Regis Prado. São Paulo: Revista dos Tribunais, 2015.

WIEACKER, Franz. História do direito privado. Tradução de A. M. Botelho Hespanha. 5. ed. Lisboa: Fundação Calouste Gulbenkian, 2015.

WORLD WILDLIFE FUND (WWF). Living planet report 2008. Disponível em: $<$ http://assets.panda.org/downloads/living_planet_report_2008.pdf $>$. Acesso em: $10 \mathrm{dez}$. 2017.

YOSHIDA, Consuelo Yatsuda Moromizato (Org.). Recursos hídricos: aspectos éticos, jurídicos, econômicos e socioambientais. 2 v. Campinas, SP: Alínea, 2007.

ZAFFARONI, Eugenio Raúl. Em busca das penas perdidas: a perda da legitimidade do sistema penal. 5. ed., 4. reimpr. Tradução de Vania Romano Pedrosa e Amir Lopez da Conceição. Rio de Janeiro: Revan, 2015.

. Prologo. In: RUDÁ, ANTONIO SÓLON. Breve história do direito penal e da criminologia. Rio de Janeiro: LumenJuris, 2013.

ZINI, Josiane et al. Estudo de metais e de substâncias tóxicas em brinquedos. Química Nova, São Paulo, v. 32, n. 4, p. 833-838, 2009 Disponível em: $<$ http://www.scielo.br/scielo.php?script $=$ sci_arttext\&pid=S0100$40422009000400002 \& \operatorname{lng}=\mathrm{en} \& \mathrm{nrm}=\mathrm{iso}>$. Acesso em: 16. nov. 2017. 